MAURÍCIO SHIMABUKURO

\title{
Diversity of annelids in organic substrates in the deep Southwest Atlantic Ocean
}

Dissertation presented to the Instituto Oceanográfico of the Universidade de São Paulo, as part of requeriments for obtaining the $\mathrm{PhD}$ degree in Sciences, Oceanography program, concentration area of Biological Oceanography.

Supervisor

Prof. Paulo Yukio Gomes Sumida 
Universidade de São Paulo

Instituto Oceanográfico

Diversity of annelids in organic substrates in the deep Southwest Atlantic Ocean

Maurício Shimabukuro

Dissertation presented to the Instituto Oceanográfico of the Universidade de São Paulo, as part of requeriments for obtaining the PhD degree in Sciences, Oceanography program, concentration area of Biological Oceanography.

Evaluated in 1

$\operatorname{Prof}(a) . \operatorname{Dr}(a)$.

Conceito

$\operatorname{Prof}(a) . \operatorname{Dr}(a)$.

Conceito

Prof(a). Dr(a).

Conceito

Prof(a). Dr(a).

Conceito

Prof(a). Dr(a).

Conceito 


\section{ACKNOWLEDGEMENTS}

I wish to thank CAPES for both the PhD scholarship and the scholarship received during the doctoral internship at Auburn University. I would also like acknowledge FAPESP for the BIOTA-FAPESP grant 2011/50185-1 to my advisor P.Y.G. Sumida, without which all my PhD would not be possible. I am also indebted to IOUSP for the infrastructure provided and the Graduate Program in Oceanography.

To my supervisor, Paulo Yukio Gomes Sumida, not only for his exceptional directions and encouragement during my $\mathrm{PhD}$, but also for his concern regarding my progress as a researcher. His constant search for new challenges was something that always inspired me. I hope I have learned from your enthusiasm and dedication.

I would like to thank Prof. Vivian H. Pellizzari and her Lab (LECOM), for the support during my work. Thank you for always leaving your lab open and for sharing moments of learning and fun. Thanks to Dr. Kenneth Halanych (Auburn University) for his guidance during the phylogenetic analysis, and for all suggestions that made my work better. I also thank Dr. Craig Smith for the financial support to participate in BOWL project cruise and the BOWLBioSuOr workshop in Friday Harbor.

I promised myself not to extend my thanks, but it is difficult not to look back and remember everything I have gone through. Not only all that I have learned, but also all friendships made during this time.

Two persons were fundamental during my PhD. I'm very grateful to Joan M. Alfaro Lucas and Romina Barbosa for their friendship and support in difficult times. For our long science discussions and fun times with a lot of food and beer. I learned a lot with you guys and despite the distance, you will always be great friends and people that I would always like to have by my side.

I thank the people from the lab for their companionship and support throughout my PhD. Many thanks to Joan, Romina, Miguel, Banha, Olívia, Thur, Bruno, Zé, Paulo (Oncinha), Laricão, Vaca, Estela. Special thanks to Sandra Bromberg, Carol Araújo, Thomás Banha and Mariana Andrade. I must extend my thanks to Mi, Paulinha, Gá, Lu e Wan, Ju, Flávia, Linda, Rosa, Diego, Amanda, Natasha, Lu, Fran, Lola, Cris, Camila, Aninha, Tulita, Claudia and Jana, friends that I made during my PhD.

My gratitude also goes to people working at IOUSP; from CPG, especially Ana, Leticia and Daniel; from the LIO team, especially Chico, Wilson and Fábio; from DOB, Tomás, Luís, Valter and Maysa; and from the library, Wagner, Marta and Cidinha. All these people help me in different stages of my work, such as during the construction the landers, preparation of cruises and during the cruises themselves. All of that made my work much easier.

Very special thanks to my godparents, Neusa and Eduardo and to my cousin Du.

This work is dedicated to my mom Fusako and my dad Minoru. Thank you for believing in me, and for feeling proud for everything I do. 


\section{INDEX}

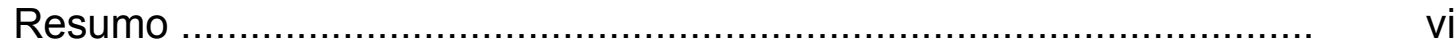

Abstract ........................................................................... vii

Chapter 1 - Annelid composition and distribution in SW Atlantic ........... 1

Abstract .............................................................................. 1

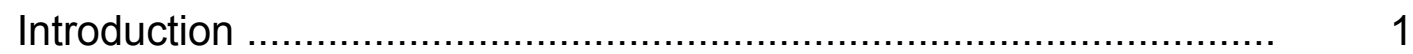

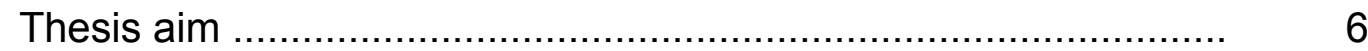

Material and methods ........................................................ 9

BioSuOr Project ......................................................................... 9

Procedures and analysis ................................................... 13

Results ............................................................................ 14

Composition and distribution ................................................. 14

Discussion ..................................................................... 16

Chapter 2 - Osedax diversity and distribution .................................. 21

Abstract ............................................................................ 21

Introduction ....................................................................... 21

Material and methods ............................................................. 24

Sample collection ............................................................. 24

Molecular data collection ....................................................... 24

Phylogenetic analysis ........................................................... 24

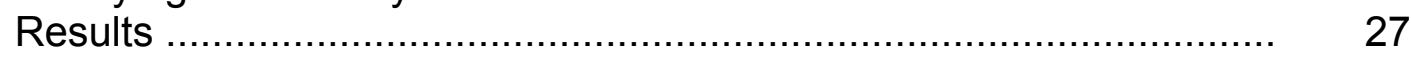

Discussion ........................................................................ 29

Chapter 3 - Whale-fall Capitella and deep-sea invasion ...................... $\quad 37$

Abstract ............................................................................. 37

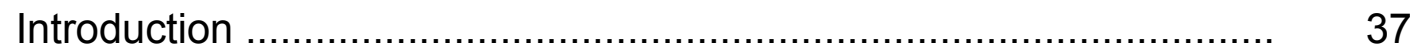

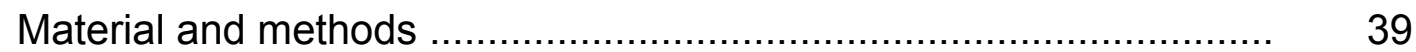

Sample collection ............................................................... 39

Molecular data collection ...................................................... 40

Phylogenetic analysis .......................................................... 41

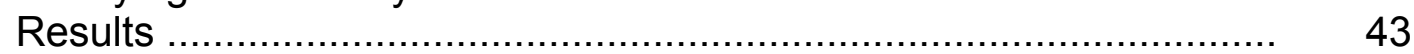

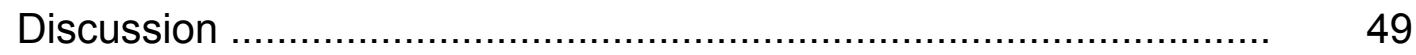

Species delineation ........................................................... 49

Has deep-sea Capitella evolved from shallow-water? ................... $\quad 52$

Chapter 4 - Diversity and phylogeny of whale-fall hesionids ................ $\quad 55$

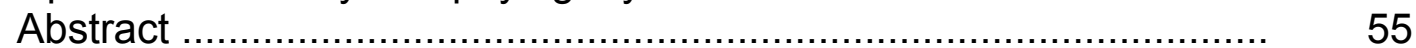

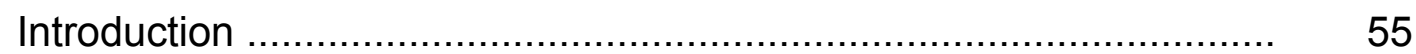

Material and methods ......................................................... 58

Sample collection ….......................................................... 58

Molecular data collection ....................................................... 59

Phylogenetic analysis ................................................................ 60

Intraspecific analysis of Vrijenhoekia balaenophila ...................... 61

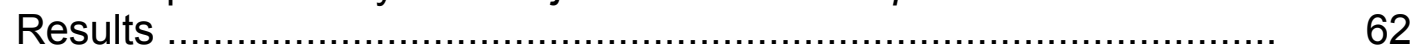

Species delimitation and phylogenetic relationship ..................... $\quad 62$

Sirsoe balaenophila species complex ........................................ 64

Systematic Account ......................................................... 66

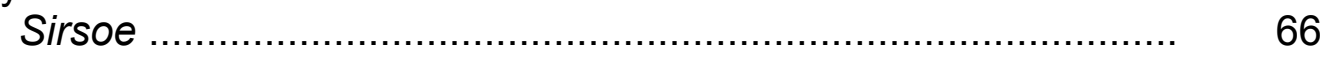

Sirsoe sirikos .................................................................. 68

Sirsoe balaenophila ................................................................ 71

Sirsoe pirapuan sp. nov. ................................................... $\quad 74$ 
Sirsoe ypupiara sp. nov. .................................................... $\quad 74$

Sirsoe maximiano sp. nov. ................................................. $\quad 75$

Sirsoe alphacrucis sp. nov. ............................................... 76

Sirsoe yokosuka sp. nov. ................................................ 79

Sirsoe alucia sp. nov. ....................................................... 81

Sirsoe nadir sp. nov. ....................................................... 84

Sirsoe alphadelphini sp. nov. ........................................... 86

Sirsoe ungava sp. nov. .................................................. 88

Sirsoe besnard sp. nov. ................................................. 89

Discussion ....................................................................... 91

Chapter 5 - General trends in whale fall diversity ............................ 95

References ........................................................................... 98 


\section{Figure Index}

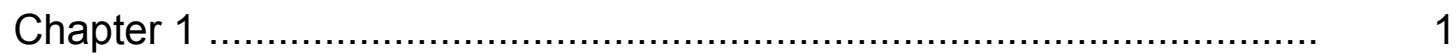

Figure 1.1. Scheme of lander ................................................... 11

Figure 1.2. A: Picture of lander and B: substrate position ................. 12

Figure 1.3. Map of the deployment site ........................................ 12

Figure 1.4. A: dendrogram and B: heatmap of annelid density ......... 15

Figure 1.5. k-means partition ....................................................... 17

Figure 1.6. PCA of annelid family ................................................ 17

Chapter 2 .......................................................................... 21

Figure 2.1. Phylogeny of Osedax recovered by Bayesian Inference .. $\quad 26$

Figure 2.2. TCS haplotype network of Osedax frakpressi ................. $\quad 30$

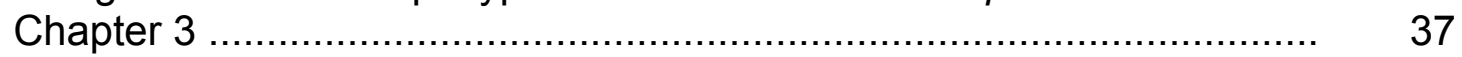

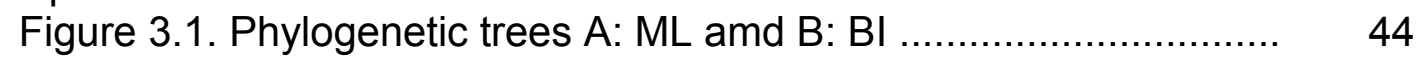

Figure 3.2. Heatmap of COI p-distances ...................................... 45

Figure 3.3. Histogram of $16 \mathrm{~S}$ p-distances ................................... 47

Figure 3.4. Phylogeny tree (ML) of A: $\mathrm{COI}+16 \mathrm{~S}$ and $\mathrm{B}$ : all genes ...... 48

Figure 3.5. Ancestral state reconstruction of habitat use .................. 49

Chapter 4 ...................................................................... 55

Figure 4.1. Phylogeny of Sirsoe (ML) of A: COI and B: 16S ............. 63

Figure 4.2. Histogram of $p$-distances for A: COI and B: 16S ............ 64

Figure 4.3. Phylogeny of Sirsoe (ML) of COI+16S .......................... 65

Figure 4.4. Haplotype network of Sirsoe balaenophila ....................... 66

Figure 4.5. Sirsoe sirikos ............................................................ 69

Figure 4.6. Sirsoe balaenophila, Sirsoe pirapuan sp. nov., and Sirsoe ypupiara sp. nov. ............................................................... $\quad 73$

Figure 4.7. Sirsoe maximiano sp. nov. ...................................... $\quad 77$

Figure 4.8. Sirsoe alphacrucis sp. nov. ......................................... $\quad 79$

Figure 4.9. Sirsoe yokosuka sp. nov. ............................................ 81

Figure 4.10. Sirsoe alucia sp. nov. ............................................. 82

Figure 4.11. Sirsoe nadir sp. nov. ................................................... 85

Figure 4.12. Sirsoe alphadelphini sp. nov. .................................... 87

Figure 4.13. Sirsoe besnard sp. nov. ........................................... $\quad 90$ 


\section{Table Index}

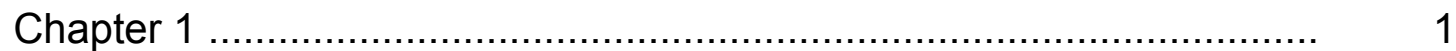

Table 1.1. Geographical coordinates and depth .............................. 13

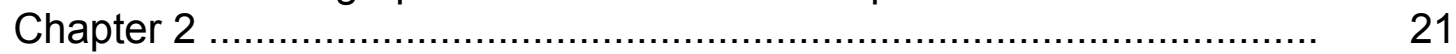

Table 2.1. COI sequences, GenBank accession numbers ................. $\quad 26$

Table 2.2. Average of COI p-distances among Osedax species ........ $\quad 30$

Table 2.3. Average of COI p-distances by codon position ................. 31

Table 2.4. Summary of genetic variability of Osedax frankpressi ....... $\quad 32$

Table 2.5. Analysis of molecular variance for Osedax frankpressi ..... 33

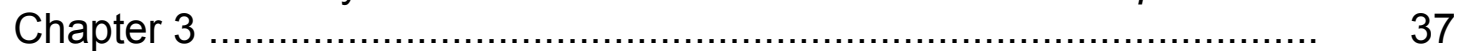

Table 3.1. Specimens employed in molecular analysis .................... $\quad 40$

Table 3.2. Average of COI p-distances among Osedax species ........ $\quad 42$

Table 3.3. Average of COI p-distances by codon position ................. $\quad 46$

Chapter 4 ............................................................................ 55

Table 4.1. Locality, depth and GenBank accession numbers ........... $\quad 62$

Table 4.2. Summary of genetic variability of COI of S. balaenophila . 65

Table 4.3. Average of p-distances among Sirsoe species for COI and $16 \mathrm{~S}$ 


\section{RESUMO}

Esta tese tem como objetivo caracterizar a diversidade de anelídeos de ossos de baleia implantados no Atlântico Sudoeste em duas profundidades diferentes (1500 e $3300 \mathrm{~m}$ ), e a relação com outras carcaças de baleia e ambientes quimiossintetizantes. $O$ primeiro capítulo apresenta uma introdução geral com uma breve revisão sobre a composição da fauna e sua importância ecológica para o ecossistema de mar profundo. O capítulo 1 também mostra a distribuição das famílias de anelídeos evidenciando que as assembleias provavelmente estão sob influência dos processos oceanográficos, tais como as características das massas d'águas e seu fluxo direcional. A diversidade do especialista de carcaça, Osedax, é abordado no capítulo 2. A distribuição das espécies de Osedax nas profundidades estudadas reforçam a importância dos processos oceanográficos na estrutura da comunidade. Neste capítulo nós também comparamos as populações do Atlântico e do Pacífico de Osedax frankpressi. Surpreendentemente, a família Capitellidae foi o anelídeo mais abundante nos ossos de baleia, e por esta razão, a diversidade de Capitella, o único gênero de capitelídeo encontrado nas carcaças, é avaliada no capítulo 3 . As relações filogenéticas entre Capitella de águas rasas e de mar profundo são apresentadas no capítulo 3 , gerando percepções sobre a invasão e diversificação do gênero no mar profundo. No capítulo 4, a diversidade e filogenia de Sirsoe e Vrijenhoekia são investigadas, evidenciando a inclusão de Vrijenhoekia dentro de Sirsoe. Dez novas espécies de Sirsoe foram descritas, algumas delas crípticas e outras compartilhadas entre as carcaças de baleia do Atlântico e do Pacífico. Apenas uma espécie nova foi previamente registrada em fontes hidrotermais. Por último, o capítulo 5 ressalta a contribuição desta tese para o conhecimento da diversidade de carcaças de baleia, sugerindo questões importantes para futuros estudos.

Palavras-chave: Carcaças de baleia, mar profundo, Atlântico SO, Osedax, Capitellidae, Hesionidae. 


\begin{abstract}
This thesis aims to characterize the annelid diversity of whale bones implanted in the SW Atlantic at two different depths (1500 and $3300 \mathrm{~m}$ ) and its relation with other whale falls and chemosynthetic environments. The first chapter presents a general introduction with a brief review on whale-fall composition and its importance to the deep-sea ecosystem. Chapter 1 also exhibits the distribution of annelid families showing that assemblages are probably under the control of oceanographic processes, such as water masses characteristics and direction of flow. The diversity of the most important whale fall specialist, Osedax, is explored in chapter 2. The distribution of Osedax species on the studied depths reinforces the importance of oceanographic processes for community structure. In this chapter we also compare Atlantic and Pacific populations of Osedax frankpressi. Interestingly, the family Capitellidae was the most abundant annelid in whale bones and, for this reason, the diversity of Capitella is evaluated in chapter 3 , the only capitellid genus found in whale falls. The phylogenetic relationships of shallow-water and deep-sea Capitella are present in chapter 3 , providing insights for the invasion and diversification of this genus in the deep-sea environment. In Chapter 4, the diversity and phylogeny of Sirsoe and Vrijenhoekia is investigated. The phylogenic analysis of both genera indicates the inclusion of Vrijenhoekia inside Sirsoe. Ten new Sirsoe species were found, some of them cryptic and some shared between Atlantic and Pacific whale falls. Only one new species was previously found in vents. Finally, chapter 5 highlights the contribution of this thesis to the knowledge of whale fall diversity, suggesting important issues for future studies.
\end{abstract}

Keywords: Whale fall, deep sea, SW Atlantic, Osedax, Capitellidae, Hesionidae. 


\title{
CHAPTER 1
}

\section{Whale-fall communities - a brief review of ecological importance and species composition}

\begin{abstract}
Whale falls are considered important habitats contributing to biodiversity, evolutionary novelty and connectivity for the deep-sea environment. The community passes through different overlapping successional stages: mobilescavenger, enrichment-opportunist and sulfophilic stages. Throughout these stages whale falls shelter background deep-sea species, mainly at mobilescavenger stage, but also specialist species and those dependent on chemosynthesis, which can be shared with cognate environments. Whale falls are likely to be common along the SW Atlantic since it is home to populations of many great whales, which are either permanent residents or migrate from/to Antarctica. Therefore, the SW Atlantic whale fall communities are probably important for the understanding of the biogeography and evolution of whale-fall species. Annelids, one of dominant whale fall groups, were represented mainly by the families Capitellidae and Hesionidae, which amount ca. $82 \%$ of all annelids. Bones implanted at $\sim 1500 \mathrm{~m}$ depth were influenced by the southward flux of the North Atlantic Deep Water (NADW) and were dominated by capitellids and hesionids. However, the annelid assemblage at SP-3300 was controled by the Antarctic Bottom Water (AABW) flowing northwards and presented a slightly different composition. The distinction in the annelid assemblages in the deeper region of the north section (RJ-3300 and ES-3300) is possibly associated to a mixture between NADW and AABW, while the main core of the AABW was present only at SP-3300. Therefore, oceanographic processes along the study area were important for the structure of whale-fall communities.
\end{abstract}

Keywords: SW Atlantic, bathymetric pattern, annelids.

\section{Introduction}

The deep sea is the largest ecosystem on Earth, with ca. 430 million $\mathrm{km}^{2}$ (Ramirez-Llodra et al., 2010; Danovaro et al., 2014). Nowadays, this ecosystem is recognized as a heterogeneous habitat that usually depends on the primary production at the sea surface. The phytoplanktonic primary productivity in the euphotic region is exported to the benthic compartment and, for the deep-sea organisms, this is the main food resource (Smith et al., 1996; Gooday, 2002; Turner, 2002). However, the organic matter flux is inversely 
proportional to water column depth and for this reason the quantity and quality of detritus is generally low in the deep sea (Turner, 2002; Buesseler et al., 2007). This happens because the particulate organic matter (POM) is usually formed by small particles that sink slowly and degrade along the water column (Turner, 2002).

Despite the small amount of POM, very large organic remains can sink rapidly to the deep sea. Because of its size, these large parcels sink fast and reach the seabed nearly intact, representing an intense enrichment to the deep seabed. These oases of food in the deep are known as organic falls or organic islands. Different kinds of organic remains can generate an organic fall, in special wood logs, kelps, gelatinous organisms and carcasses of large vertebrates (Turner, 1973; Wolff, 1979; Smith, 1985; Smith et al., 1989; Billett et al., 2006; Higgs et al., 2014).

Whales are ecosystem engineers with strong influence on the marine ecosystem mainly as reservoirs and vectors of nutrient to different compartments of the ocean (see more in Roman et al., 2014). When they die, their massive carcasses reach to seafloor rapidly and almost intact (Smith \& Baco, 2003; Smith, 2006). In fact, whale carcasses have been considered as important food sources to deep-sea organisms for a long time (Krogh, 1934; Stockton \& DeLaca, 1982). A recently arrived 40-ton gray whale carcass in the seabed is equivalent to more than 2,000 years of background carbon flux to the sediment just below it (Smith, 2006).

The intense organic enrichment caused by a whale carcass drives a specific faunal composition along at least three overlapping successional stages (Bennett et al., 1994; Smith et al., 2002; Smith \& Baco, 2003; Braby et al., 2007; Lundsten et al., 2010a). These successional stages are: 1) mobilescavenger, 2) enrichment-opportunist, and 3) sulfophilic stages. Moreover, a fourth and last stage was hypothesized; the reef stage occurs after the consumption of all organic content from whalebones remaining only the mineral matrix (Smith \& Baco, 2003). However, this stage can happen only in particularly occasions as when manganese encrusts the whalebone or in the complete absence of a specialized fauna that degrade the mineral matrix (Lundsten et al., 2010a; Higgs et al., 2011a; Smith et al., 2015). 
In the first stage, the mobile-scavenger, the main resource is the flesh and the adipose tissue that are consumed by necrophages (Smith \& Baco, 2003). The duration of this stage is from few months to some years depending on the abundance of necrophages, scavenging rate and carcass size (Smith \& Baco, 2003). The mobile-scavenger stage itself undergoes a temporal succession with the tissue been consumed first by megafaunal necrophages, such as sleeper sharks, hagfishes, macrourids, and lithodid and galatheid crabs, changing to a dominance of macrofaunal necrophages such as lysianassid amphipods, some isopods and echinoderms (Hessler et al., 1978; Smith et al., 2002; Smith \& Baco, 2003). In general, however, a generalist fauna that are usually found in background habitats dominate this stage (Goffredi et al., 2004; Glover et al., 2010; Lundsten et al., 2010a, 2010b; Smith, K. et al., 2014).

The consumption of soft tissue by necrophages expands the enrichment to the sediments around the carcass as well as exposes the bones. A dense assemblage of heterotrophic invertebrates colonizes the sediments and bones characterizing the enrichment-opportunist stage (Smith \& Baco, 2003). At this stage, the density of macro-invertebrates can increase 10-25 times reaching $50,000 \mathrm{ind} . / \mathrm{m}^{2}$ in sediments close to the carcass (Smith et al., 2014). Annelids are one of the most important fauna and their density may be high, such as that of the chrysopetalid Boudemos flokati, which can reach up to 40,000 ind. $/ \mathrm{m}^{2}$ living in the bones (Smith \& Baco, 2003). In contrast, species richness is dramatically reduced in the enrichment-opportunist stage (Smith \& Baco, 2003; Smith et al., 2014). Despite the dominance of few species, many of them are only known at whale falls such as $B$. flokati and B. ardabilia (Dahlgren et al., 2004; Wiklund et al., 2009a), some dorvilleids (Wiklund et al., 2009b, 2012), polynoids (Pettibone, 1993; Glover et al., 2005a), and hesionids of the genera Sirsoe and Vrijenhoekia (Pleijel et al., 2008; Summers et al., 2015).

The microbial decomposition of the organic matter from the carcass, mainly the lipids from the bones, is extremely important since it increases reduced compounds in the bones and sediments (Deming et al., 1997; Smith \& Baco, 2003). At the beginning, the decomposition occurs aerobically, but the intense bacterial activity rapidly decreases oxygen content. Assemblages of 
sulfur-reducing bacteria and methane-oxidizing archaea are important to the anaerobic decomposition of organic matter (Deming et al., 1997; Goffredi et al., 2008; Treude et al., 2009). This degradation process leads to higher sulfide and methane effluxes, defining the sulfophilic stage (Smith et al., 1989; Naganuma et al., 1996; Deming et al., 1997; Smith \& Baco, 2003; Treude et al., 2009).

During the sulfophilic stage, dense microbial mats are found in bones and sediments as a result of the high level of reduced compounds that are exploited by free-living chemoautotrophic microorganisms (Smith et al., 1989; Smith \& Baco, 2003; Lundsten et al., 2010a; Amon et al., 2013; Sumida et al., 2016; Alfaro-Lucas et al., 2017). The chemosynthetically-derived carbon is extremely important to some heterotrophic fauna at this stage (Smith \& Baco, 2003; Glover et al., 2005a; Alfaro-Lucas et al., 2018). Moreover, invertebrates bearing chemosynthetic symbionts are also found in the sulfophilic stage, e.g., the siboglinids Escarpia spicata, Lamellibrachia satsuma, L. barhami, and many bathymodioline and vesycomyid bivalves (Smith et al., 1989; Feldman et al., 1998; Baco et al., 1999; Distel et al., 2000; Smith et al., 2002; Smith \& Baco, 2003; Fujiwara et al., 2007; Lundsten et al., 2010b).

The chemosynthetic production is the main factor driving community structure at the sulfophilic stage, similarly to what happens in cognate environments, such as vents and seeps. Furthemore, Smith et al. (1989) reported affinities in the faunal composition of whale-falls, vents and seeps. For these reasons, whale-falls were considered as important steeping-stones for the dispersal of deep-sea fauna that depends on chemosynthetic production (Smith et al., 1989; Smith et al., 2002; Smith \& Baco, 2003). This idea was controversial at the beginning since most affinities were based on high taxonomic levels (Tunnicliffe \& Juniper, 1990). However, at present it appears reasonable that the whale-falls could provide intermediate habitats for some species to disperse between isolated habitats, such as vents, expanding its geographic distribution range (Smith et al., 2015).

The increasing knowledge of whale-fall habitats has been proving that they share species (and also lineages) with vents, seeps and other organic islands, such as wood-falls (Naganuma et al., 1996; Baco et al., 1999; Fujiwara et al., 2007; Lundsten et al., 2010b; Amon et al., 2013; Teixeira et al., 2013; 
Glover et al., 2005a; Hilário et al., 2015; Ravara et al., 2015; Sumida et al., 2016; Smith et al., 2017). This is the case for the siboglinids Escapia spicata, Lamellibrachia satsuma and L. barhami (Smith et al., 1989; Naganuma et al., 1996; Lundsten et al., 2010b), the alvinocaridid shrimp Alvinocaris muricola (Teixeira et al., 2013; Pereira et al., in prep.), and Hyalogyrina rissoela (Smith et al., 2014; Souza et al., in prep).

The importance of whale-falls facilitating the dispersion among chemosynthetic environments has a potential implication for the evolution of some lineages. The molecular phylogeny of deep-sea mussels shows that species occurring in whale- and wood-falls, usually with extracellular symbionts, are basal lineages to vents and seeps species, with intracellular symbionts (Distel et al., 2000; Lorion et al., 2009, 2013; Fujiwara et al., 2010; Miyazaki et al., 2010). Moreover, the new molecular phylogeny of deep-sea chrysopetalid annelids shows that bacterivorous species living in whale-falls are basal to parasitic linages (parasitic in deep-sea vent and seep bivalves) (Watson et al., 2016). These studies suggest that organic falls were important stepping-stones, serving as intermediate habitats where several adaptations were acquired (e.g., physiological tolerance to reduced compounds, acquisition of symbiont or exploitation of new niches), facilitating the colonization of extremely reduced environments (vents and seeps).

On the opposite direction, a biogeographic network using a reduced dataset (without some whale-fall sites and only for some specific mollusk clades), shows that whale sites have low connection with vents and seeps (Kiel, 2016). However, re-analyzing the network only for the Pacific Basin whale-falls (where more whale-falls are known), Kiel (2017) found higher connectivity with other chemosynthetic habitats. This highlights the importance to increase the knowledge of deep-sea whale-falls by sampling more sites, especially in different ocean basins. Moreover, a global connectivity pattern among deep-sea reducing communities needs the inclusion of all taxa, since most shared species among these habitats are annelids (Smith et al., 2017). It is likely that whale-falls may be important stepping-stones for some groups and not for others. 
Many new species, including organisms with novel adaptations, have been described in deep-sea whale falls in the last years. One of the most remarkable examples is the bone-eating annelid Osedax (Rouse et al., 2004). The first incredible adaptation of this worm is the marked sexual dimorphism. In all but one known case, Osedax males are paedomorphic, resembling trochophora larvae, living on the trunk and tubes of females (Rouse et al., 2004, 2008, 2015; Worsaae \& Rouse, 2010). According to the first studies, sex is environmentally determined (ESD) in Osedax, since the density of females in whalebones do not increase along time whereas the number of males in female tubes progressively increases, forming harems of dwarf males (Rouse et al., 2004, 2008). Despite ESD evidence for Osedax, dwarf males with spermatids were observed settled on bones (Miyamoto et al., 2013). Moreover, Rouse et al. (2015) discovered Osedax priapus with non-dwarf males. Clearly, ESD is important for Osedax but a role of genetic sex determination may still exist (Rouse et al., 2015).

Osedax females lack mouth and digestive system (Rouse et al., 2004) and they penetrate into the bone using a root-like tissue that degrade the bone matrix by a proton pump mechanism, similarly to the osteoclast cells of vertebrates (Tresguerres et al., 2013). Female roots host aerobic heterotrophic bacteria that degrade organic contents, mainly collagen, from the bones being the main food resource for them (Goffredi et al., 2005, 2007, 2013). The eroding activity of Osedax truncates and shortens the sulfophilic stage, impeding the development of the reef stage in whale fall communities, especially in smaller carcasses (Braby et al., 2007; Lundsten et al., 2010a; Higgs et al., 2011a, b; Smith et al., 2015; Sumida et al., 2016; Alfaro-Lucas et al., 2017). Even though Osedax degradation accelerates the decomposition of the bone it also increases bone structural complexity facilitating colonization by other organisms in its innermost matrices. This ultimately leads to the enhancement of local diversity (Alfaro-Lucas et al., 2017). For this reason, Osedax act as an important ecosystem engineer in whale falls (Alfaro-Lucas et al., 2017).

\subsection{Thesis aim and objectives}

The Southwest Atlantic margin is an important area to study whale falls since it is a migratory route, as well as a residence region for many whale 
populations. For example, the sub-Antarctic population of humpback whale migrates from South Georgia Islands through Rio Grande Rise and northwards to the Abrolhos Bank, which is a nursery area for this population (Zerbini et al., 2006). Assuming that the population of humpback whales, which breeds on the Brazilian margin, was about 20,300 individuals in 2012 (Bortolotto et al., 2017) and using the same natural mortality rate and percentage of sink carcasses from Smith \& Baco (2003) (0.05 ind.yr ${ }^{-1}$ and 50\%, respectively), an estimate ca. 507 humpback carcasses may exist on the seafloor at the mobile-scavenger stage along this migratory route. Moreover, assuming equal durations for each successional stage (sensu Smith \& Baco, 2003) there are maybe between $\sim 760$ and 5,019 carcasses at the enrichment-opportunist and sulfophilic stages, respectively laying on the seafloor of this region. With inclusion of the South Atlantic population of Antarctic minke whales with a population of about 58,400 individuals (IWC, 2013), there may be a combined total of ca. 1,967 carcasses in mobile-scavenger, 2,950 in enrichment-opportunist and 19,473 in the sulfophilic stage in the South Atlantic, only considering these two great whale species. In fact, eight baleen whales are found in Brazilian margin, six of which with migratory routes between the Southern Ocean and Brazil (Santos et al., 2010). Moreover, the SW Atlantic margin is home and/or migratory route for at least 22 toothed whales (Santos et al., 2010). The cosmopolitan distribution of some whales, such as sperm whales, may probably supply Brazilian equatorial waters too (Smith \& Baco, 2003; Smith et al., 2015). The Bryde's whale also permanently inhabits Brazilian waters from equatorial latitudes to southern Brazil, together with the false killer, killer and short- and long-finned pilot whales. In addition, Brazilian islands, seamounts and oceanic mountain chains are also frequently visited by cetaceans and thus potentially enhance carcasses sunk around these areas (Lodi et al., 1996; Silva \& Godoy, 2010; Wedekin et al., 2014).

Even though whale falls can be worldwide distributed and the South Atlantic Ocean host many populations, almost all whale fall studies have been undertaken in the Pacific Basin, mainly in its Northeast region (Smith et al., 1989, 2002, 2014, 2017; Goffredi et al., 2004; Braby et al., 2007; Lundsten et al., 2010a, b). It is extremely important to increase the sampling effort in whale 
falls from different regions around the world to understand the global diversity and role of whale-fall communities (Smith et al., 2017). Whale falls house a lot of specialist species or those only found in deep-sea chemosynthetic communities, contributing fundamentally to biodiversity, evolutionary novelty, connectivity and ecosystem function within deep-sea ecosystem (Smith et al., 1989, 2014, 2015; Baco \& Smith, 2003; Smith \& Baco, 2003; Braby et al., 2007; Lundsten et al., 2010a, b; Bernardino et al., 2012; Amon et al., 2013; Hilário et al., 2015; Sumida et al., 2016).

In this context, my thesis has as overall goal to characterize and describe aspects of annelid diversity in whale falls from the SW Atlantic Ocean, comparing the composition with other whale falls around the world and also with other chemosynthetic environments. Moreover, since some annelids are specially diversified in whale falls and others are widespreadly distributed on chemosynthetic sites, in each chapter I will focus on the ecological role of whale falls in the diversification and dispersion of deep-sea annelids. There is still little information on deep-sea annelid composition in the SW Atlantic, especially in whale falls. Therefore, in this chapter (Chapter I) I will summarize the annelid family composition in SW Atlantic whale falls and their distribution in two different depths (1500 and $3300 \mathrm{~m}$ ). In the next chapters I will use one whalefall specialist group (Osedax) and two dominant families focusing the following specific objectives:

In Chapter 2 I identify Osedax species from the SW Atlantic Ocean using DNA barcoding, mitochondrial gene cytochrome-c oxidase subunit 1 (COI) to compare different depths (1500 and $3300 \mathrm{~m}$ ).

In Chapter $3 \mathrm{I}$ investigate the molecular diversity of Capitella from organic falls (whale and wood) and analyze the phylogenetic relationship between deep-sea and shallow-water species. While Capitella is common in shallow organically-enriched sites, it is almost absent in the background oligotrophic deep-sea (Grassle \& Grassle, 1976; Blake, 2009; Blake et al., 2009; Silva et al., 2016). However, Capitella is abundant in deep-sea chemosynthetic environments, including organic falls (Levin et al., 2009; Silva et al., 2016; Alfaro-Lucas et al., 2017). With this in mind, in chapter 3 I will try to answer the following questions: Has deep-sea Capitella evolved from the 
shallow-water species? If so did they use organic falls to reach the deep sea? Did the invasion of deep-sea happen only once or multiple times?

In Chapter $4 \mathrm{I}$ evaluate the diversity of Hesionidae in the SW Atlantic whale-falls using morphological and molecular taxonomy. I will also explore the presence of the hitherto Pacific species Vrijenhoekia balaenophila in the SW Atlantic investigating cryptic speciation and interbasin (Pacific vs. Atlantic) distribution. Moreover, using new data from the SW Atlantic I will also reevaluate the systematics of whale-fall hesionids.

Finally, in Chapter $5 \mathrm{I}$ synthetize the discoveries of the previous chapters highlighting the progress made on the knowledge of whale-fall diversity and function while reflecting on the directions for future studies.

\section{Material and methods}

\subsection{BioSuOr Project - General material and methods of the thesis}

My thesis is part of the BioSuOr project (Biodiversity and Connectivity of Benthic Communities in Organic Substrates in the Deep Southwest Atlantic FAPESP: 2011/50185-1). However, I have also used material from a natural whale-fall found during the latá-Piúna Expedition in the SW Atlantic (see in Sumida et al., 2016) using the research submersible Shinkai 6500. In Chapter 3, I included material from the BoWL Project (Bone-Wood Lander) from the NE Pacific Ocean, a BioSuOr sister project financed by the US National Science Foundation and coordinated by $\mathrm{Dr}$ Craig Smith from the University of Hawaii.

Project BioSuOr was conceived to study the biota associated with organic falls in the SW Atlantic Ocean (from microbes to megafauna), in order to understand bathymetric patterns, trophic ecology, and the role of specialist species in the degradation of organic substrates (whalebone and wood).

Since it is not easy to find a natural organic fall due to the sheer size of the deep ocean, our sampling was made by the deployment and recovery of experimental autonomous structures (landers). The landers were aluminumbuild prism-shaped structures (Figures 1.1a-1.1i), with each face composed of three boxes lined by meshed bags $(500 \mu \mathrm{m})$ and a PVC lid (Figure 1.1i and $1.2 \mathrm{~A}$ and $\mathrm{B}$ ). Each lander was outfitted with an acoustic release (Teledyne 
Benthos 866A), where ballast was fixed, and glass sphere buoys (MacLane Labs Inc.) for flotation upon recovery. The weight of the ballast was calculated to sink the whole lander including floats. Moreover, the buoyancy was calculated to bring the lander back to the sea surface when the ballast was released.

We used whalebones and wood as organic substrates. All whalebones used were thoracic vertebrae from a humpback whale (Megaptera novaeangliae). The vertebrae were collected on 23 October 2012 from a stranded carcass in the Pontal do Ipiranga beach (Linhares/ES). Intervertebral discs and vertebrae processes were removed using a handsaw (Figure 1.2B). A transversal section was made in each vertebra and all pieces were kept frozen $\left(-20^{\circ} \mathrm{C}\right)$ until the deployment. The wood used in the experiment was from a pine tree (Pinus elliottii), which was donated by the Klabin Company (Figure 1.2). The wood log was cut in dimensions similar to those of the whale vertebrae.

The organic substrates (whalebone and wood) were attached to each face of the landers inside the box and on the lid, totaling three pieces into the box and three on the lid (Figure 1.1i and 1.2A and B). Therefore, we had six samples per lander of each organic substrate (Figure 1.1h). Pieces from boxes and lids corresponded to the same vertebra, as each vertebra was transversally cut. Control substrates were made of vinyl pool mat and were fabricated in the same shape as bones and wood. Six control substrates were similarly attached to each lander.

Landers were deployed in two depths (1500 and $3330 \mathrm{~m}$ ) and three transects (SP, RJ and ES, between $21^{\circ}$ and $25^{\circ} \mathrm{S}$ ) (Figure 1.3. Table 1.1). Three major water masses are found along the deep Brazilian margin: Antarctic Intermediate Water (AAIW), North Atlantic Deep Water (NADW), and Antarctic Bottom Water (AABW) (De Madron \& Weatherly, 1994; Silveira et al., 2000). In our study, NADW generally flows southward at depths of $1200-3000 \mathrm{~m}$ to $\sim 32^{\circ} \mathrm{S}$ (McCartney, 1993). The temperature of NADW is between 3 and $4{ }^{\circ} \mathrm{C}$, with salinity around 35 on the southeast Brazilian margin (De Madron \& Weatherly, 1994; Silveira et al., 2000). Below $\sim 3000$ m, AABW generally flows northward, via Vema Channel, which was originated mainly by Lower Circumpolar Deep Water (De Madron \& Weatherly, 1994; Stramma \& England, 1999). This layer of 
AABW flows in the Brazilian Basin between 3100 and $4100 \mathrm{~m}$ depth (Hogg \& Owens, 1999). The temperature of $\mathrm{AABW}$ in this region is above $0^{\circ} \mathrm{C}$, up to $2^{\circ}$ C, with salinity below 35 (Stramma \& England, 1999).

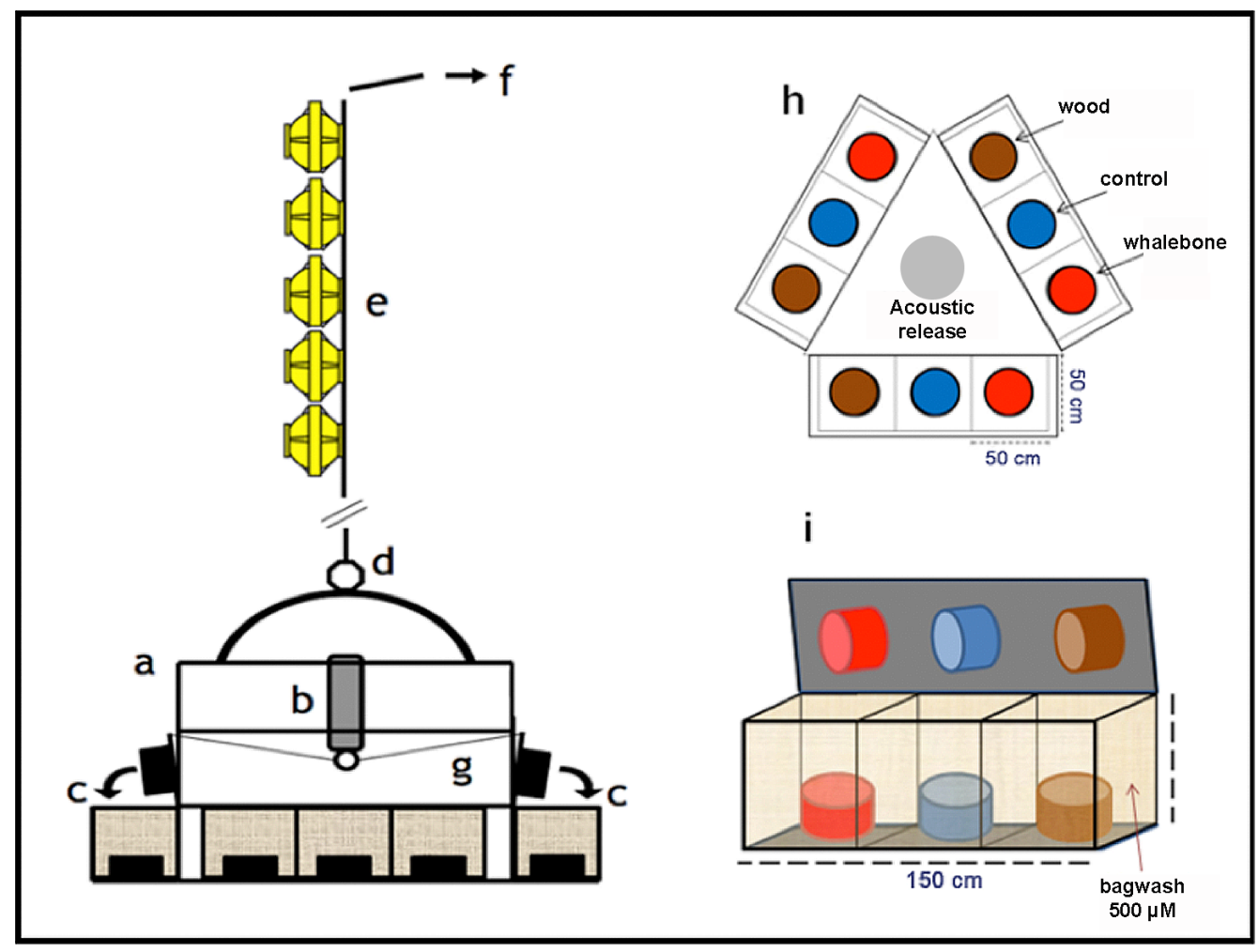

Figure 1.1 - Scheme of lander: a - lander lateral view; b - acoustic release; $c$ - lid of the boxes; $d$ superior part of lander frame where the glass buoy was attached; $\mathrm{e}$ - buoy set; $\mathrm{g}$ - connections of lids to the acoustic release; $h$ - lander viewed from above; $i$ - individual boxes set of each lateral face of the lander.

The deployment cruise occurred between 28 May and 06 June 2013 on board the R/V Alpha-Crucis. The lander deployed at SP-1500 was recovered 16 months later on 09 October 2014 on board the R/V Alpha Delphini. Other landers were recovered between 18 - 28 May 2015 on board the Polar R/V Almirante Maximiano from the Brazilian Navy. Unfortunately, the lander RJ1500 was lost during recovery. An extra lander was deployed in a pockmark field in the South section of Santos basin at 550 m depth on July 2016 on board of R/V Alpha Crucis and recovered on May 2018 on board of M/V Alucia. 

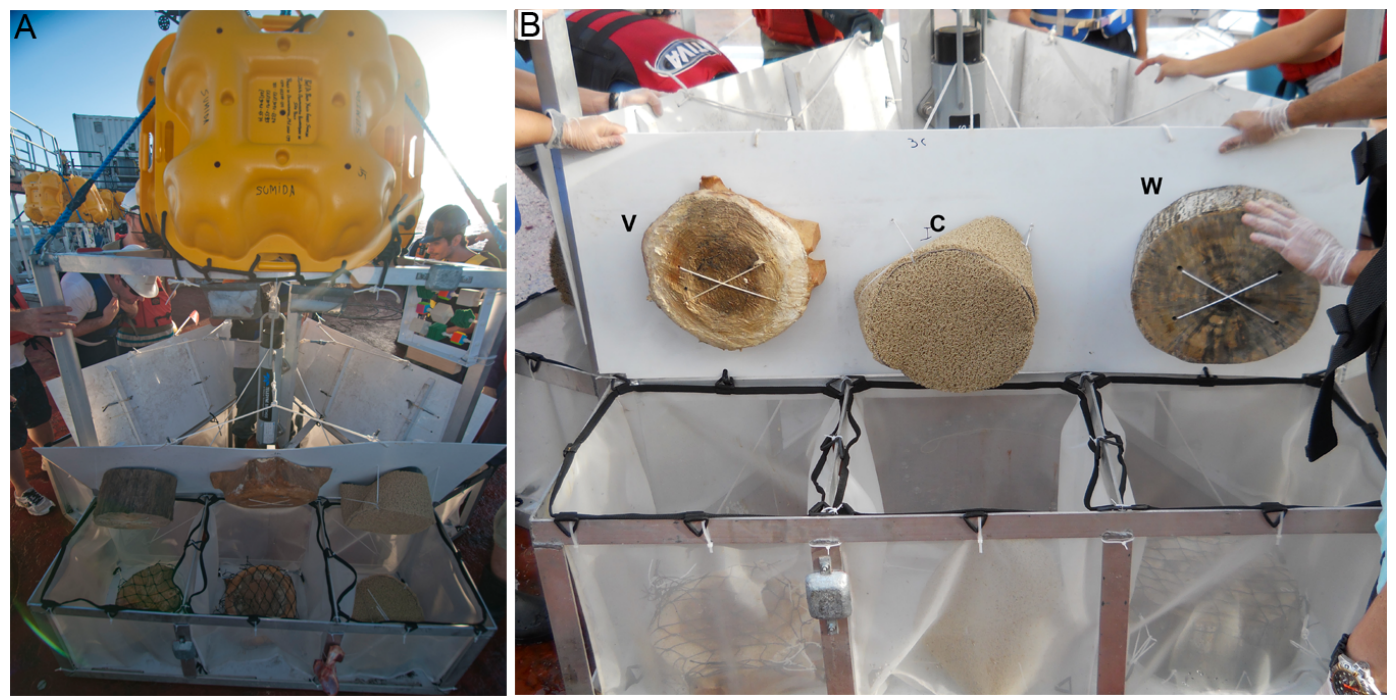

Figure 1.2 - A: picture of the lander with the substrates; B: Positions of organic substrates and control in one face of the lander. "V" - whale vertebrae; "C" - control substrate; "W" - wood.

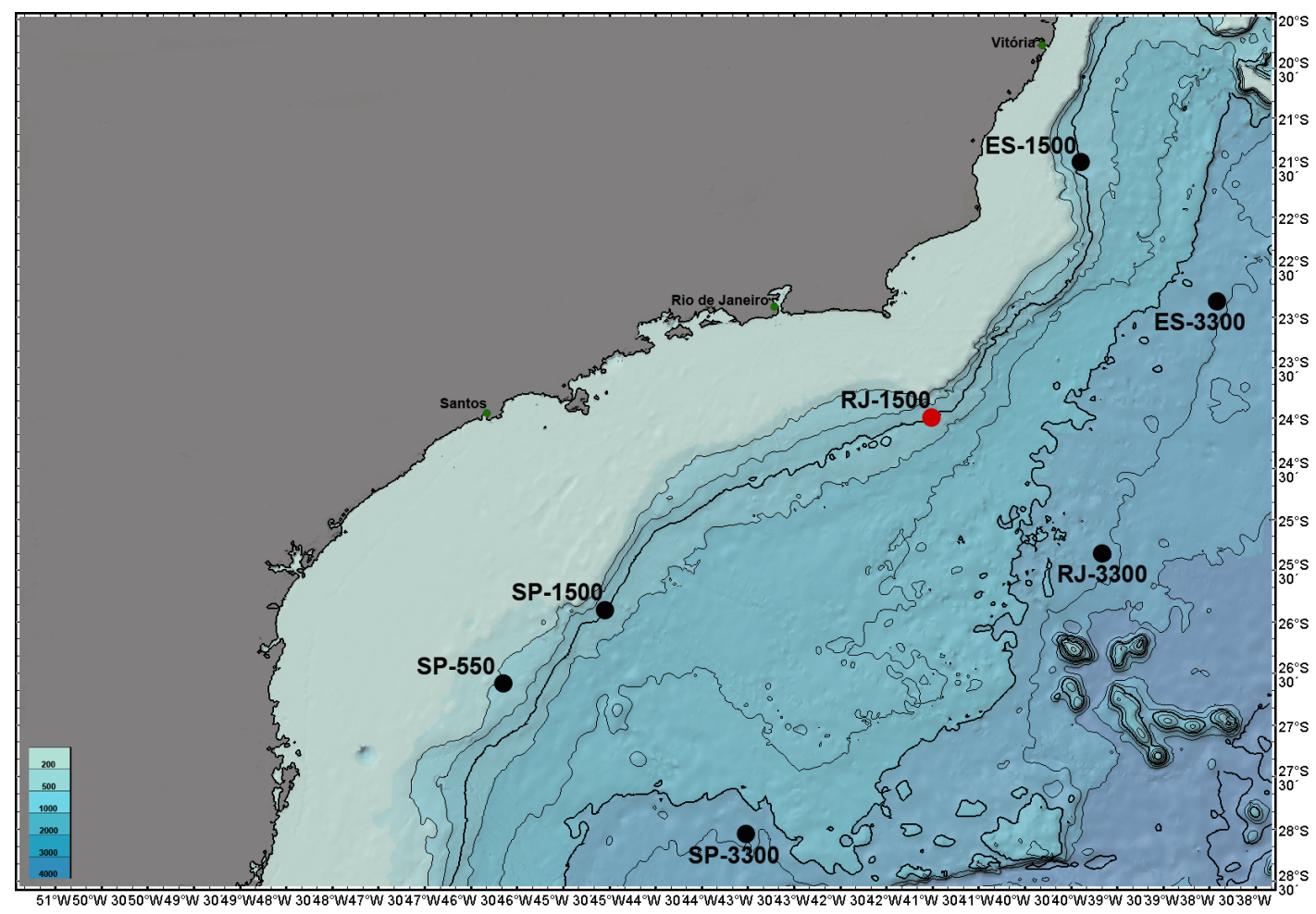

Figure 1.3 - Map of the deployment sites. Black circles represent the landers recovered while the red circle represents the lander lost. Isobath lines between $500-4000 \mathrm{~m}$ depth; dark lines are 1500 and $3500 \mathrm{~m}$ depth, respectively.

Immediately after recovery, substrates were maintained in $4^{\circ} \mathrm{C}$ filtered seawater refrigerated by high power chillers. Substrates were photographed and the epifauna was sorted on board. Each substrate was sub-sampled into four pieces. A quarter of the bone was partially sorted on board. The epi- and endofauna from bones and woods, were hand-picked with forceps on board for 
molecular and isotopic analyses. The quarter that was initially sorted on board was preserved in $96^{\circ}$ ethanol, another quarter was frozen and two quarters were individually fixed in formalin $4 \%$.

Table 1.1 - Geographical coordinates and depth of each lander

\begin{tabular}{cccc}
\hline Lander & Latitude & Longitude & Depth \\
\hline SP-1500 & $25^{\circ} 55^{\prime} \mathrm{S}$ & $045^{\circ} 00^{\prime} \mathrm{W}$ & 1439 \\
SP-3300 & $27^{\circ} 45^{\prime} \mathrm{S}$ & $043^{\circ} 40^{\prime} \mathrm{W}$ & 3328 \\
RJ-1500 & $24^{\circ} 00^{\prime} \mathrm{S}$ & $041^{\circ} 30^{\prime} \mathrm{W}$ & 1345 \\
RJ-3300 & $25^{\circ} 40^{\prime} \mathrm{S}$ & $040^{\circ} 07^{\prime} \mathrm{W}$ & 3227 \\
$\mathrm{ES}-1500$ & $21^{\circ} 20^{\prime} \mathrm{S}$ & $039^{\circ} 45^{\prime} \mathrm{W}$ & 1444 \\
ES-3300 & $22^{\circ} 50^{\prime} \mathrm{S}$ & $038^{\circ} 25^{\prime} \mathrm{W}$ & 3211 \\
\hline \hline SP-550 & $26^{\circ} 36^{\prime} \mathrm{S}$ & $046^{\circ} 09^{\prime} \mathrm{W}$ & 550 \\
\hline
\end{tabular}

\subsection{Procedures and analysis of Chapter I}

Vertebrae fixed in formalin were transferred to ethanol $70 \%$ after the recovery cruise. One quarter of the whalebones fixed in formalin was sorted under the stereomicroscope and organisms identified at family level. Bones from boxes were sorted for SP-3300, RJ-3300, ES-3300 and ES-1500, while a bone from the lid was sorted for SP-1500. As the sorting process of bones is very time-consuming, bones were stained with Rose Bengal and only one quarter per lander was sorted. Volume was measured for all bone quarters. Annelid family data was standardized to $100 \mathrm{~cm}^{3}$ in order to compare different sorted bones.

Multivariate analyses were performed with inclusion of all data in $\mathrm{R}$ language. Species matrix was transformed by $\log _{(x+1)}$ followed by Hellinger distance transformation. Hellinger transformation is an appropriate alternative resulting in distances monotonically related to a spatial gradient as recovered with Bray-Curtis dissimilarity coefficient (Legendre \& Gallagher, 2001). Cluster analysis was performed using Ward method following Murtagh \& Legendre (2014) using hclust() function, in package stats, and the argument methods="ward.D2". K-means partitioning method was implemented to access the best partition of sampling sites. The cascadeKM() function, in vegan package, was used to run multiple k-means, with only two partition in argument 
inf.gr=2 and the maximum partition of four groups in argument sup.gr=4. Moreover, 100 random starting for each value of $\mathrm{K}$, inter $=100$, and criterion="ssi" (Simple structure Index) were used to access the best partition. In order to explore family composition in each cluster and the respective density of each family in each cluster the vegemite() function, of vegan package, was used to reorder and display site-by-family data constructing a heat map using the function heatmap(). We used the transformed $\left(\log _{(x+1)}\right)$ matrix as the density matrix in vegemite().

The principal component analysis (PCA) was also performed to compare annelid family assemblages of whalebone from different depths. Family data were also log transformed followed by Hellinger distance transformation. PCA is a linear method using Euclidean distance and therefore it is not adequate for species abundance data. For this reason data was transformed by Hellinger pre-transformation (Legendre \& Gallagher, 2001). The rda() function was used to run PCA and biplot() function was used to construct the graphic with argument scaling $=2$.

\section{Results}

3.1 Characterization of annelid composition and distribution at 1500 and $3300 \mathrm{~m}$ depths in the SW Atlantic whale falls

The bottom water temperature in SP-1500 and ES-1500 was $3.7^{\circ} \mathrm{C}$ and $3.8^{\circ} \mathrm{C}$, respectively, while in RJ-3300 and ES-3300 it was $2.4^{\circ} \mathrm{C}$. The lowest temperature was $1^{\circ} \mathrm{C}$ in SP-3300. The bottom water salinity ranged from 34.2 to 34.9.

A total of 3,461 annelids were found in whalebones, all polychaetes except one oligochaete. The oligochaete was excluded from the analyses. Annelids represented about $25 \%$ of bone endofauna, with eight families: Ampharetidae, Amphinomidae, Capitellidae, Chrysopetalidae, Dorvilleidae, Hesionidae, Siboglinidae and Spionidae. Amphinomidae was exclusive in 1500 $m$ depth, while Chrysopetalidae only occurred in ES-3300 and Spionidae in SP3300 . 
The dendrogram clustered samples according to depth (Figure 1.4A). However, the annelid assemblage from RJ-3300 and ES-3300 was closer related from each other than to SP-3300 (Figure 1.4A). According with the "Simple Structure Index" (ssi) criterion the best partition is three groups: SP1500+ES-1500, RJ-3300+ES-3300 and SP-3300 (Figure 1.5). Capitellidae and Hesionidae have higher densities in bones from $1500 \mathrm{~m}$ than in $3300 \mathrm{~m}$ depth (Figure 1.4B). Notwithstanding, Siboglinidae density was higher in SP-1500 and SP-3300 in comparison with other sites from the same isobaths (Figure 1.4B).

The first PCA axis accumulated $55.1 \%$ of the total variance (eigenvalue of 11.1) and revealed the difference between depth, with bones from $1500 \mathrm{~m}$ in the right and bones from $3300 \mathrm{~m}$ in the opposite side (Figura 1.6). The second axis $(7.2 \%)$ separated SP-3300 from the other stations (Figura 1.6). According with the PCA, Capitellidae was the main family in samples from $1500 \mathrm{~m}$ depth, while Dorvilleidae and Ampharetidae were more important in RJ-3300 and ES3300. Siboglinidae and Spionidae were responsible for the separation of SP3300 from the other sites.

A

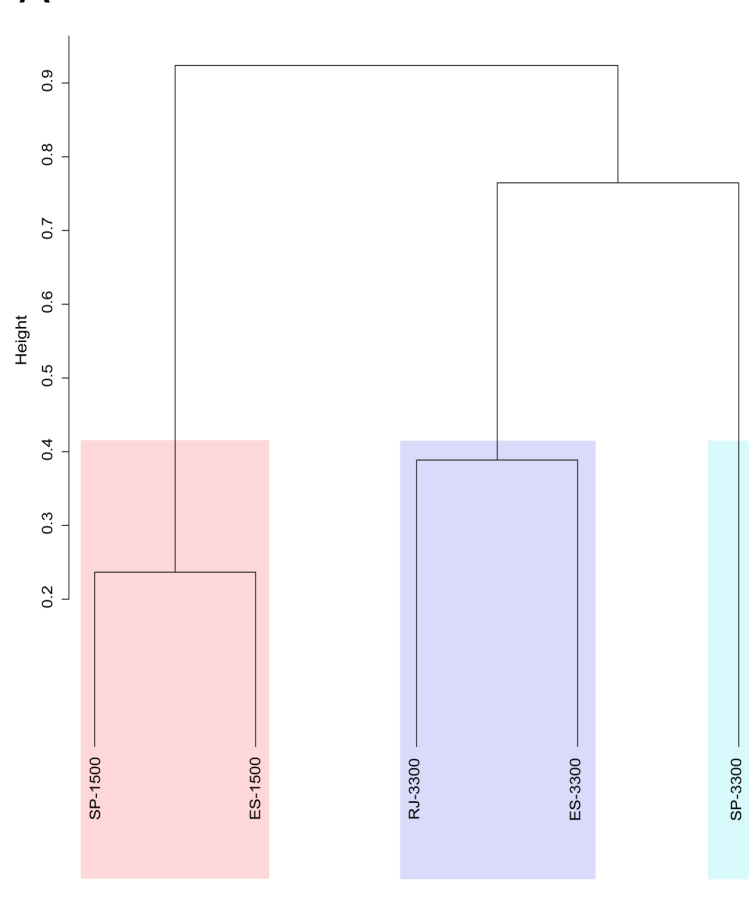

B

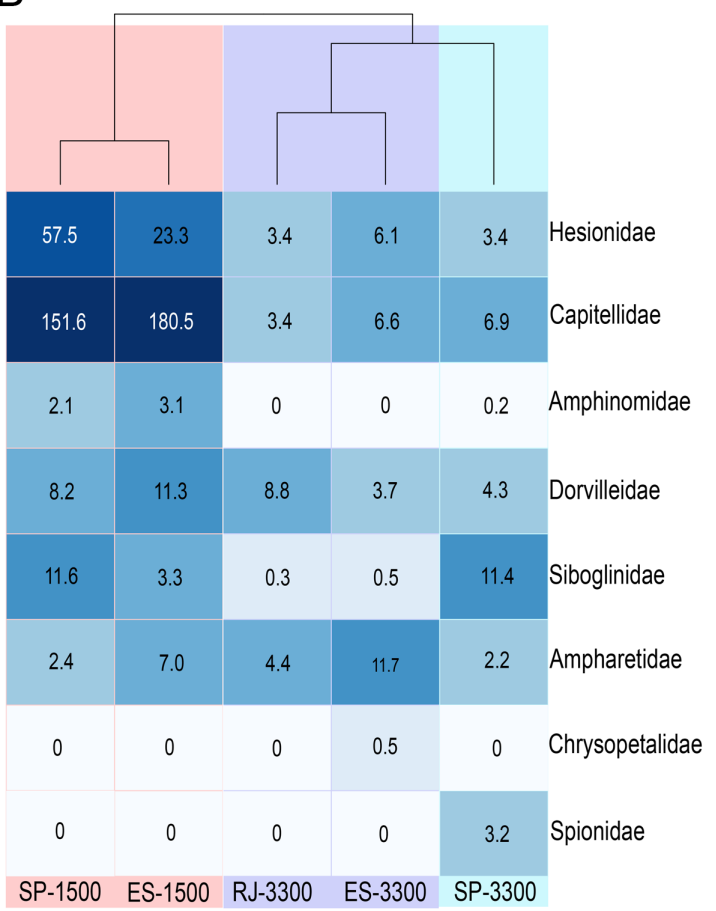

Figure 1.4 - A: dendrogram constructed by Ward method using Hellinger pre-transformed data; $B$ : Heatmap doubly ordered density annelid matrix with Ward dendrogram. 


\section{Discussion}

Annelids are usually abundant in whale falls both in sediments, on bone surface and also inside, living in the spaces of the trabecular system (AlfaroLucas et al., 2017). One of the dominant annelid family is Dorvilleidae, which is also the most diverse annelid in whale falls (Smith \& Baco, 2003; Wiklund et al., 2009b, 2012; Smith et al., 2014; Ravara et al., 2015). However, almost all whale fall studies evaluate only the sediment macroinfauna or those living on the surface of the bones or in few millimeters inside the bones. In the present study, careful investigation of the bone matrix showed a diverse and abundant endofauna heterogeneously distributed in close association with the lipid distribution inside bones. Other important factors include the position of bones either in contact with the sediment or under the direct influence of the water column and also according to the presence or absence of the ecosystem engineer, the bone-eating annelid Osedax (Alfaro-Lucas et al., 2017). Even though bone endofauna are characterized by high number of dorvilleid species, the most dominant annelids are capitellids (Alfaro-Lucas et al., 2017). A dominance of Capitellidae was also found in vertebrae implanted at $1500 \mathrm{~m}$ depth. Moreover, the high abundance of capitellids was probably associated with the presence of chemosynthetic biofilms on bones (Perez, 2016). Capitella iatapiuna, a species from a SW Atlantic whale fall, relies on chemosynthetically derived carbon (Alfaro-Lucas et al., 2018), which is also common for several other Capitella species (Tsutsumi et al., 2001).

Interestingly, our study also revealed a high abundance of hesionids inside whalebones. Six species of Vrijenhoekia, one Sirsoe, one Microphthalmus and one Pleijelius are presented in Chapter 4. The high diversity and abundance of hesionids in whale bones might be related to niche partitioning (Alfaro-Lucas et al., 2018). Partition of food resources is also thought to be the main reason for high dorvilleid diversity in methane seeps, and potentially in other chemosynthetic environments as well (Thornhill et al., 2012).

Siboglinids were represented only by Osedax in our study. Osedax is a vertebrate bone specialist since it can also occurs in skeleton of big fishes, turtles, seals, and also in implanted pig and cow bones (Jones et al., 2008; Kiel 
et al., 2011; Hilário et al., 2015; Rouse et al., 2018). Although, Osedax seems to be the most common siboglinid in whale falls, vestimentiferans and Sclerolinum also occur in this environment (Smith et al., 1989; Feldman et al., 1998; Lundsten et al., 2010b). The bone-eating worm was present in all stations in our study even though they did not form dense clusters on bones probably because of the relative short time of bone exposure in the bottom (Figure 1.4B).

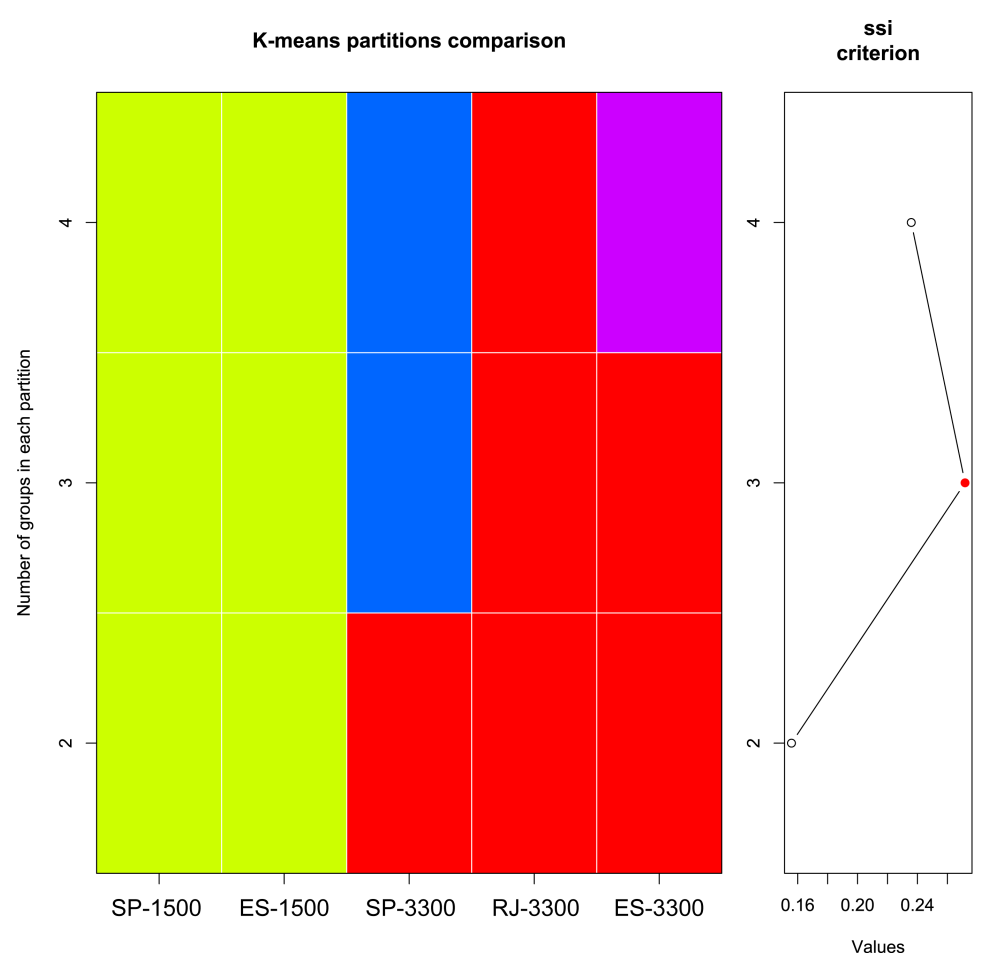

Figure 1.5 - K-means partitioning, cascade plot showing stations. Simple structure index (ssi) value shown best partition.

Despite of that, Osedax can quickly colonize bones after few months and reach a dense population in whale falls (Braby et al., 2007; Lundsten et al., 2010a). The colonization is usually associated to the bone type (Amon et al., 2013; Lundsten et al., 2010a) although different Osedax species can exploit different resources (Lundsten et al., 2010a; Higgs et al., 2011a, b; Amon et al., 2013; Rouse et al., 2018). The lipid content of the bones explain the pattern of colonization along skeleton since caudal vertebrae, the most lipid rich bones, are usually the last bones resting during the degradation process, while thoracic vertebrae are rapidly degraded due to the low lipid content (Higgs et al., 2011a). All our bones were thoracic vertebrae from an adult humpback whale. We 
expected a high colonization by Osedax, since bones with low lipid content are rapidly colonized and degraded by organisms (including microbiota) (Higgs et al.,

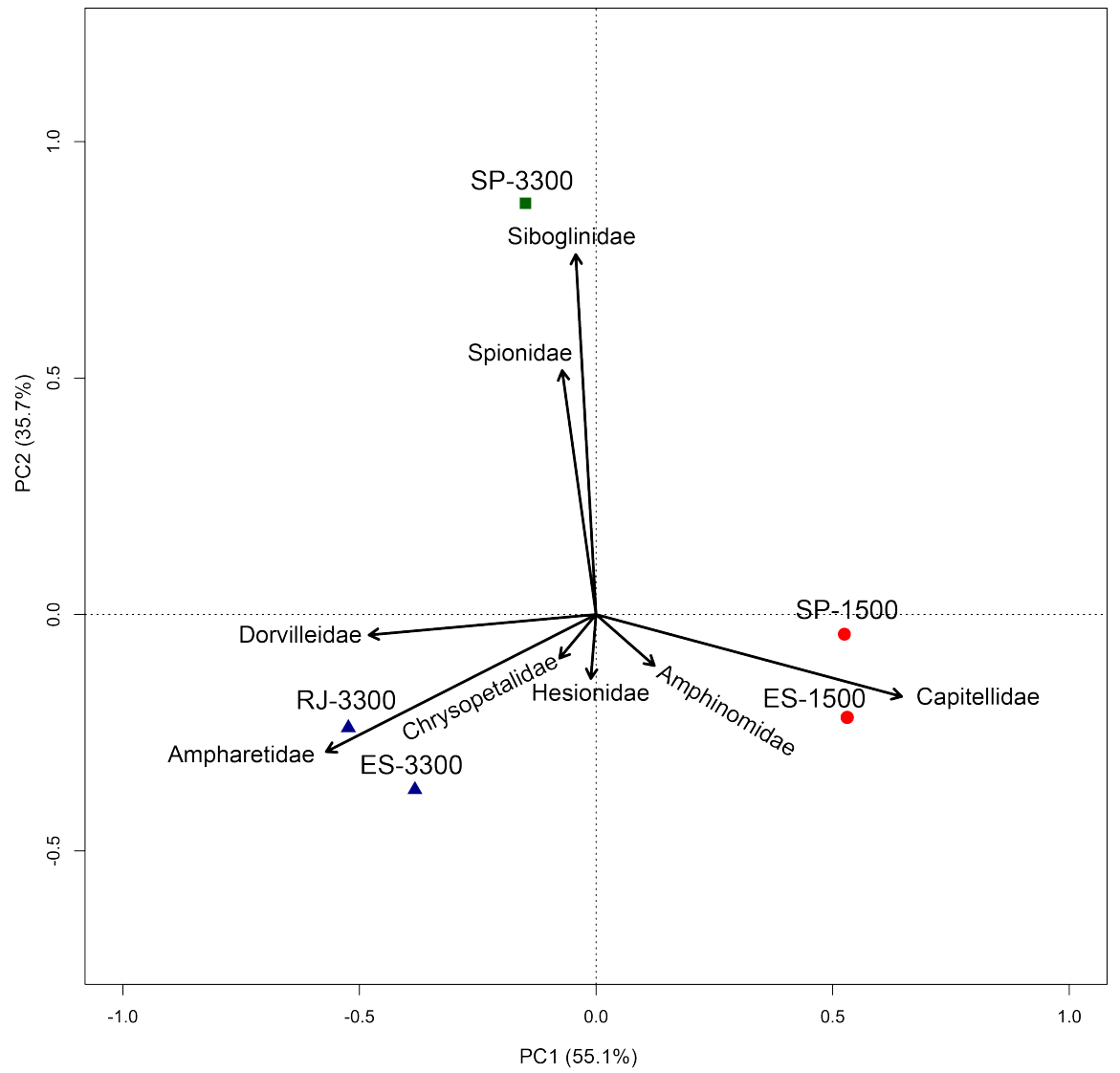

Figure 1.6 - Principal component analysis (PCA) of annelid family data. Values close to each axis are percentage of the total variance concentrated in their respective axes. Red circles - landers at $\sim 1500 \mathrm{~m}$ depth; blue triangles and green square - landers at $\sim 3300 \mathrm{~m}$ depth. Close to each symbol is typed the lander station name.

2011a). Notwithstanding, adult whales usually have more lipid content than juveniles and also more calcified bones preventing a rapid release of the lipid reservoir (Smith \& Baco, 2003). It is possible that the low density of Osedax is related to the higher lipid content of an adult whale carcass, even in thoracic vertebrae. Previous observations of higher colonization of Osedax in thoracic vertebrae were made in juvenile carcasses (Lundsten et al., 2010a) or in adults of Antarctic minke whale (Amon et al., 2013). Compared to other great whales, minke whales are one of the smallest balaenopterids reaching up to 10 meters and 10 tons. On the other hand, an adult of humpback whale can reach a weight of up to 36 tons. Therefore, it is expected that the lipid reserve of a humpback whale be larger with slower degradation rates (Smith \& Baco, 2003). Additionally, we also implanted cow bones (femurs and tibia), and the degradation of these bones by Osedax were faster in comparison with 
whalebones (data not shown). Small cetaceans, such as dolphins, porpoise and seals, but also other mammals as cow carcasses, have much lower lipid content and bones are less calcified in comparison with great whales leading to shorter community time spans (Jones et al., 1998, 2008; Kemp et al., 2006; Dahlgren et al., 2006; Glover et al., 2010; Higgs et al., 2011a; Hilário et al., 2015).

This study revealed differences in annelid whalebone assemblages according to depth. Bathymetric patterns in whale fall communities are attributed to environmental conditions such as water column temperature and dissolved oxygen concentration (Lundsten et al., 2010a). Moreover, high sedimentation rates and frequent turbidity flows in the upper slope may reduce whale fall species richness. At deeper sites, diversity increases probably due to lower disturbance rates (Braby et al., 2007; Lundsten et al., 2010a). In canyons for instance, disturbance and enrichment effects are the main factors structuring the benthos (Vetter \& Dayton, 1998) and similar results were obtained for whale falls within these enviroments (Braby et al., 2007, Lundsten et al., 2010a). Besides, the presence of an oxygen minimum zone in Monterey Canyon has also an important influence on the community between 500 and $1500 \mathrm{~m}$ depth (Braby et al., 2007; Lundsten et al., 2010a).

Even though, we did not measure oxygen concentration in our study, both water masses present in the deep SW Atlantic basin are oxygen-rich (Mémery et al., 2000). According to the temperature and salinity of bottom water, samples at $1500 \mathrm{~m}$ depth were under the influence of North Atlantic Deep Water (NADW), while SP-3300 was under the influence of Antarctic Bottom Water (AABW) (Hogg et al., 1999; Stramma \& England, 1999; Silveira et al., 2000). However, RJ-3300 and ES-3300 had low temperatures, but slightly higher than SP-3300 indicating a mixture region between NADW and AABW (Silveira, personal comm.). It is possible that the observed differences among whale-fall annelid assemblages may derived from water mass differences in each site, which seems remarkable at SP-3300. Both water masses, NADW and AABW, are components of Deep Western Boundary Current (DWBC) along the SW Atlantic flowing in opposite directions. While NADW flows southward (2000 - 3100 m depth), AABW flows northward (3100 - 
4100 m) (De Madron \& Weatherly, 1994; Hogg et al., 1999; Stramma \& England, 1999).

In the present study, benthic larvae entrained in different water masses may have played a crucial role during substrate colonization. Ocean currents are known for their importance for larval dispersion (Cowen \& Sponagle, 2009; Young et al., 2012; Breusing et al., 2016). Therefore, bones at $1500 \mathrm{~m}$ under NADW influence, supposedly supplied by the same larval pool explains the similarity between these different latitudinal sites. Interestingly, some hesionids and Osedax found only in SP-3300 also occurred in the natural SW Atlantic whale fall (see in next chapters), both under AABW influence. Macrofaunal structure from implanted wood during this experiment, also showed a depth pattern $(1500$ vs. $3300 \mathrm{~m})$ and a latitudinal trend at $3300 \mathrm{~m}$ depth, with composition, diversity and abundance at SP-3300 differing from those at RJ3300 and ES-3300 (Saeedi et al., in prep). These observations reinforce the idea that water masses and their direction trajectory may influence the communities of organic falls at the deep SW Atlantic basin, linking those under their path.

Our initial results on annelid family composition and structure emphasize the importance of oceanographic processes for whale-fall community structure. Further investigations on species composition of the whole community and also studies on genetic connectivity among sites may reinforce this hypothesis. 


\section{CHAPTER 5}

\section{General trends in whale-fall diversity and future perspectives}

Whale falls are remarkable habitats yielding an unusual energy-rich environment in the deep sea, and sustaining a tolerant background fauna, specialists and shared species with cognate environments. The high organic input associated with sulfide and/or methane production increases the dominance of few species in accordance with Pearson \& Rosenberg model for organic-enrichment sites (Smith \& Baco, 2003; Bernardino et al., 2012; Smith et al., 2014). However, whalebones are not homogenously colonized by different species, presenting a mosaic of microhabitats within bones and also along the carcass, enhancing the presence of rare species and, consequently, the overall diversity of whale falls (Higgs et al., 2011; Smith et al., 2015; Alfaro-Lucas et al., 2017).

In this study, we found 27 annelid species associated with deep-sea whale falls distributed in three families: Siboglinidae (Chapter 2), Capitellidae (Chapter 3) and Hesionidae (Chapter 4). All Siboglinidae species found in this study were Osedax and therefore exclusive of vertebrate carcasses. Capitellids of genus Capitella, usually uncommon in deep-sea background sediments, totaled seven lineages in the SW Atlantic and two in the NE Pacific associated with organic falls (Chapter 3 ). Within Hesionidae, we only focused in Sirsoe and in the formerly genus known as Vrijenhoekia, which was included within Sirsoe in this study (Chapter 4). Initial identification of material from BioSuOr, revealed that Microphthalmus and Pleijelius (two incertis sedis in Hesionidae) were also present inside whalebones (Chapter 1), the latter being also found in wood falls (Saeedi et al., in prep). Then, it is possible that the diversity of this family could be higher than expected.

Considering only these three families and species studied here $\sim 74 \%$ were only found in whale falls. Inclusion of Siboglinidae in this analysis could inflate the percentage of exclusive species in whale falls since Osedax is the most species-rich genus of the family. Other siboglinids are also found in whale falls, such as Sclerolinum, Escarpia and Lamellibrachia (Smith et al., 
1989; Feldman et al., 1998; Lundsten et al., 2010b), even though only Osedax were found here (Chapter 1 ). Excluding Siboglinidae, $\sim 66.7 \%$ of the species were exclusive in whale falls in our study. Moreover, $\sim 9.5 \%$ were exclusive in wood falls, $\sim 19 \%$ were present in whalebones and woods, $\sim 4.8 \%$ were shared between whale fall and vents and none of the species were known in deep-sea background. Therefore, this study shows the importance of exclusive species in whale falls highlighting the contribution of whale falls to the global diversity of deep-sea ecosystem.

It is known that some whale-fall species dependent on chemosynthesis are shared with cognate sites. Geological and biological evidence point out that seeps could be common along the deep Brazilian margin (Shimabukuro et al., submitted). Accordingly, future investigations focusing on seeps in the SW Atlantic could help to understand the distribution of fauna dependent on chemosynthesis and if these species utilize whale falls as stepping-stones for dispersion between chemosynthetic sites. Up to date, this study show that Sirsoe maximiano is a shared species between MidCayman Spreading Center vents and SW Atlantic whale falls (Chapter 4), and may be also distributed in seeps along Brazilian margin. Furthermore, the presence of shared species between whale falls and vents, demonstrated by this work, support that whale falls are used as stepping stones for dispersion among chemosynthetic environments.

The annelid composition found in SW Atlantic whale falls exhibited some dissimilarities in comparison with other whale falls around the world. Capitellids, for instance, are abundant and diverse in SW Atlantic whale falls whereas dorvilleids are usually the dominant annelid family in whale falls from NE Pacific, Southern Ocean, NE Atlantic and SW Indian Ocean (Smith \& Baco, 2003; Wiklund et al., 2009, 2012; Amon et al., 2013, 2017; Hilário et al., 2015). Notwithstanding, dorvilleids were also present in SW Atlantic but in low densities. Its diversity should be addressed in future researches. Both families are very tolerant to high sulfide concentrations relying on chemosynthetic production. It is possible that capitellids are occupying the same ecological niche in SW Atlantic whale falls that dorvilleids occupy in other basins. 
The phylogeny of Capitella provides evidence that this genus originated in the shallow water and invaded the deep sea two times (Chapter 3). Capitella could have used organic falls to invade the deep sea, since this habitat supplies the food resources necessary for its development. Therefore, this work reinforces that whale falls are evolutionary stepping-stones to invasion of deep sea chemosynthetic environments, as proposed by Smith \& Baco (2003) and illustrated by the evolutionary history of the deep-sea mussels, bathymodioline (Distel et al., 2000, Miyazaki et al., 2010; Lorion et al., 2013).

Although the dominance of capitellids in the SW Atlantic could be an indicative of segregation of whale falls among basins, this study highlight the presence of three species with inter basin distribution (Pacific and Atlantic): Osedax frankpressi, Sirsoe balaenophila and Sirsoe sirikos. Genetic distances associate with low number of substitutions between haplotypes from both ocean basins indicate the proximity between populations of these whale-fall species. Although this is not common for chemosynthetic fauna, a few seep species are also known in both Pacific and Atlantic oceans (Sibuet et al., 1998). Atlantic connection with eastern Pacific may have occurred through the open Isthmus of Panama (Tunnicliffe et al., 1996; Barry et al., 1997). This also could be one route for connection between fauna of whale falls. Moreover, continental margins are regions were whale falls are likely to be frequent, facilitating stepping-stones dispersal of some whale-fall fauna and connecting whale falls around the world. Future investigations are necessary to better understand if Atlantic and Pacific populations are connected, focusing in the larval dispersal capability, in biophysical models to predict the routes through which they are connect, and also increasing the sampling effort between both areas. 


\section{REFERENCES}

Ahrens, J.B.; Borda, E.; Barroso, R.; Paiva, P.C.; Campbell, A.M.; Wolf, A.; Nugues, M.M.; Rouse, G.W. \& Schulze, A. (2013). The curious case of Hermodice carunculata (Annelida: Amphinomidae): evidence for genetic homogeneity throughout the Atlantic Ocean and adjacent basins. Mol. Ecol. 22, 2280-2291.

Alalykina, I. (2013). Preliminary data on the composition and distribution of polychaetes in the deep-water areas of the north-western part of the Sea of Japan. Deep Sea Res. II 86-87, 164-171.

Alfaro-Lucas, J. M., Shimabukuro, M., Ferreira, G. D., Kitazato, H., Fujiwara, Y. \& Sumida, P. Y. (2017). Bone-eating Osedax worms (Annelida: Siboglinidae) regulate biodiversity of deep-sea whale-fall communities. Deep Sea Res. II 146, 4-12.

Alfaro-Lucas, J.M., Shimabukuro, M., Ogata, I., Fujiwara, Y. \& Sumida, P.Y.G. (2018). Trophic structure and chemosynthetic controbution to heterotrophic fauna inhabiting an abyssal whale carcass. Submitted to Mar. Ecol. Prog. Ser. (in press). Doi:10.3354/meps12617.

Álvarez-Campos, P., Giribet, G. \& Riesgo, A. (2017a). The Syllis gracilis species complex: a molecular approach to a difficult taxonomic problem (Annelida, Syllidae). Mol. Phylogenetics Evol. 109, 138-150.

Álvarez-Campos, P.; Giribet, G.; San Martín, G.; Rouse, G.W. \& Riesgo, A. (2017b). Straightening the striped chaos: systematics and evolution of Trypanosyllis and the case of its pseudocryptic type species Trypanosyllis krohnii (Annelida, Syllidae). Zool. J. Linn. Soc. 179, 492-540.

Amon, D. J., Wiklund, H., Dahlgren, T. G., Copley, J. T., Smith, C. R., Jamieson, A. J. \& Glover, A. G. (2014). Molecular taxonomy of Osedax (Annelida: Siboglinidae) in the southern ocean. Zool. Scr. 43(4), 405-417.

Amon, D.J., Copley, J.T., Dahlgren, T.G., Horton, T., Kemp, K.M., Rogers, A.D. \& Glover, A.G, (2017). Observations of fauna attending wood and bone deployments from two seamounts on the Southwest Indian Ridge. Deep Sea Res. II 136, 122-132.

Amon, D.J., Glover, A.G., Wiklund, H., Marsh, L., Linse, K., Rogers, A.D. \& Copley, J.T. (2013). The discovery of a natural whale fall in the Antarctic deep sea. Deep Sea Res. II, 92, 87-96.

Audzijonyte, A. \& Vrijenhoek, R. C. (2010). When gaps really are gaps: statistical phylogeography of hydrothermal vent invertebrates. Evolution 64(8), 2369-2384.

Baco, A.R. \& Smith, C.R. (2003). High species richness in deep-sea chemoautotrophic whale skeleton communities. Mar. Ecol. Prog. Ser. 260, 106-114.

Baco, A.R., Smith, C.R., Peek, A.S., Roderick, G.K. \& Vrijenhoek, R.C. (1999). The phylogenetic relationships of the whale-fall vesicomyid clams based on mitochondrial COI DNA sequences. Mar. Ecol. Prog. Ser., 182, 205-223.

Barroso, R., Klautau, M., Solee-Cava, A.M. \& Paiva, P.C. (2010). Eurythoe complanata (Polychaeta: Amphinomidae), the 'cosmopolitan' fireworm, consists of at least three cryptic species. Mar. Biol. 157, 69-80.

Bennett, B.A., Smith, C.R., Glaser, B. \& Maybaum, H.L. (1994). Faunal community structure of a chemotrophic assemblage on whale bones in the deep northeast Pacific Ocean. Mar. Ecol. Prog. Ser., 108, 205-223.

Bernardino, A.F., Levin, L.A., Thurber, A.R. \& Smith, C.R. (2012). Compartive composition, diversity and trophic ecology of sediment macrofauna at vents, seeps and organic falls. PLoS ONE 7(4), e33515.

Bernardino, A.F.; Berenguer, V. \& Ribeiro-Ferreira, V.P. (2016). Bathymetric and regional changes in benthic macrofaunal assemblages on the deep Eastern Brazilian margin, SW Atlantic. Deep Sea Res. I 111, 110-120.

Billett, D.S.M., Bett, B.J., Jacobs, C.L., Rouse, I.P. \& Wigham, B.D. (2006). Mass deposition of jellyfish in the deep Arabian Sea. Limnol. Oceanogr., 51(5), 2077-2083.

Blair, N.E.; Levin, L.A.; DeMaster, D.J. \& Plaia, G. (1996). The short-term fate of fresh algal carbon in continental slope sediments. Limnol. Oceanogr. 41(6), 1208-1219. 
Blake, J. A. (1985). Polychaeta from the vicinity of deep-sea geothermal vents in the eastern Pacific. I. Euphrosinidae, Phyllodocidae, Hesionidae, Nereididae, Glyceridae, Dorvilleidae, Orbiniidae, and Maldanidae. Bulletin of the Biological Society of Washington, 6, 67-101.

Blake, J.A. (2009). Redescription of Capitella capitata (Fabricius) from West Greenland and designation of a neotype (Polychaeta, Capitellidae). Zoosymposia, 2, 55-80.

Blake, J.A. and Narayanaswamy, B.E. (2004). Benthic infaunal communities across the Weddell Sea basin and South Sandwich slope, Antarctica. Deep Sea Res. II 51, 17971815.

Blake, J.A., Grassle, J.P. \& Eckelbarger, K.J. (2009). Capitella teleta, a new species designation for the opportunistic and experimental Capitella sp. I, with a review of the literature for confirmed records. Zoosymposia, 2, 25-53.

Borda, E., Kudenov, J. D., Chevaldonné, P., Blake, J. A., Desbruyères, D., Fabri, M. C., Hourdez, S., Pleijel, F., Shank, T.M., Wilson, N.G., Schulze, A. \& Rouse, G.W. (2013). Cryptic species of Archinome (Annelida: Amphinomida) from vents and seeps. Proc. R. Soc. B 280(1770), 20131876.

Bortolotto, G.A., Danielewicz, D., Hammond, P.S., Thomas, L. \& Zerbini, A.N. (2017). Whale distribution in a breeding area: spatial models of habitat use and abundance of western South Atlantic humpback whales. Mar. Ecol. Prog. Ser. 585, 213-227.

Braby, C.E., Rouse, G.W., Johnson, S.B., Jones, W.J. \& Vrijenhoek, R.C. (2007). Bathymetric and temporal variation among Osedax boneworms and associated megafauna on whalefalls in Monterey Bay, California. Deep Sea Res. I, 54, 1773-1791.

Brasier, M.J., Wiklund, H., Neal, L., Jeffreys, R., Linse, K., Ruhl, H. \& Glover, A.G. (2016). DNA barcoding uncovers cryptic species diversity in $50 \%$ of deep-sea Antarctic polychaetes. R. Soc. Open sci., 3, 160432.

Breaker, L. C. \& Broenkow, W. W. (1994). The circulation of Monterey Bay and related processes. Oceanogr. Mar. Biol. 32, 1-64.

Breusing, C., Biastoch, A., Drews, A., Metaxas, A., Jollivet, D., Vrijenhoek, R.C., Bayer, T., Melzner, F., Sayavedra, L., Petersen, J.M., Dubilier, N., Schilhabel, M.B., Rosenstiel, P. \& Reusch, T.B.H. (2016). Biophysical and population genetic models predict the presence of "Phantom" stepping stones connecting Mid-Atlantic Ridge Vent ecosystems. Curr. Biol. 26(17), 2257-2267.

Buesseler, K.O., Lamborg, C.H., Boyd, P.W., Lam, P.J., Trull, T.W., Bidigare, R.R., Bishop, J.K.B., Casciotti, K.L., Dehairs, F., Elskens, M., Honda, M., Karl, D.M., Siegel, D.A., Silver, M.W., Steinberg, D.K., Valdes, J., Mooy, B.V. \& Wilson, S. (2007). Revisiting carbon flux through the ocean's twilight zone. Science, 316(5824), 567-570.

Castresana, J. (2000). Selection of conserved blocks from multiple alignments for their use in phylogenetic analysis. Molecular biology and evolution, 17(4), 540-552.

Clement, M., Snell, Q., Walker, P., Posada, D., \& Crandall, K. (2002, April). TCS: estimating gene genealogies. In ipdps (p. 0184). IEEE.

Cowen, R.K. \& Sponaugle, S. (2009). Larval dispersal and marine population connectivity. Annu. Rev. Mar. Sci. 1, 443-466.

Cuomo, M C. (1985). Sulphide as a larval settlement cue for Capitella sp I. Biogeochemistry $1(2), 169-181$.

Dahlgren, T.G., Glover, A.G., Baco, A. \& Smith, C.R. (2004). Fauna of whale falls: systematics and ecology of a new polychaete (Annelida: Chrysopetalidae) from the deep Pacific Ocean. Deep Sea Res. I, 51(12), 1873-1887.

Dahlgren, T.G., Wiklund, H., Källstrom, B., Lundälv, T., Smith, C.R. \& Glover, A.G. (2006). A shallow-water whale-fall experiment in the north Atlantic. Cah. Biol. Mar. 47, 385-389.

Danovaro, R., Snelgrove, P. V., \& Tyler, P. (2014). Challenging the paradigms of deep-sea ecology. Trends Ecol. Evol., 29(8), 465-475.

Darriba, D., Taboada, G. L., Doallo, R., \& Posada, D. (2012). jModelTest 2: more models, new heuristics and parallel computing. Nature methods, 9(8), 772-772.

De Madron, X.D. \& Weatherly, G. (1994). Circulation, transport and bottom boundary layers of the deep currents in Brazil Basin. J. Mar. Res. 52, 583-638. 
Deming, J., Reysenbach, A.L., Macko, S.A. \& Smith, C.R. (1997). The microbial diversity at a whale fall on the seafloor: bone-colonizing mats and animal-associated symbionts. Microsc. Res. Techniq., 37, 162-170.

Desbruyeres, D. \& Toulmond, A. (1998). A new species of hesionid worm, Hesiocaeca methanicola sp. nov.(Polychaeta: Hesionidae), living in ice-like methane hydrates in the deep Gulf of Mexico. Cahiers de biologie marine, 39(1), 93.

Distel, D.L., Baco, A.R., Chuang, E., Morrill, W., Cavanaugh, C. \& Smith, C.R. (2000). Marine ecology: do mussels take wooden steps to deep-sea vents? Nature ,403(6771), 725-726.

Druffel, E.R. \& Robison, B.H. (1999). Is the deep sea on a diet?. Science 284(5417), 11391140.

Dubilier, N. (1988). H2S - A settlement cue or a toxic substance for Capitella sp. I larvae?. The Biological Bulletin 174(1), 30-38.

Eckelbarger, K. J., Young, C. M., Llodra, E. R., Brooke, S. \& Tyler, P. (2001). Gametogenesis, spawning behavior, and early development in the "iceworm" Hesiocaeca methanicola (Polychaeta: Hesionidae) from methane hydrates in the Gulf of Mexico. Mar. Biol. 138(4), 761-775.

Eckelbarger, K.J. \& Watling, L. (1995). Role of phylogenetic constraints in determining reproductive patterns in deep-sea invertebrates. Invert. Biol. 114(3), 256-269.

Eilersten, M.H.; Georgieva, M.N.; Kongsrud, J.A.; Linse, K.; Wiklund, H.; Glover, A.G. \& Rapp, H.T. (2018). Genetic connectivity from the Arctic to the Antarctic: Sclerolinum contortum and Nichomache lokii (Annelida) are both widespread in reducing environments. Sci. Rep. 8, 4810. DOI:10.1038/s41598-018-23076-0

Elias, M., Hill, R.I., Willmott, K.R., Dasmahapatra, K.K., Brower, A.V.Z., Mallet, J. \& Jiggins, C.D. (2007). Limited performance of DNA barcoding in a diverse community of tropical butterflies. Proc. R. Soc. Lond. B 274(1627),

Excoffier, L. \& Lischer, H.E. (2010). Arlequin suite ver 3.5: a new series of programs to perform population genetics analyses under Linux and Windows. Mol. Ecol. Resour. 10(3), 564-567.

Feldman, R.A., Shank, T.M., Black, M.B., Baco, A.R., Smith, C.R. \& Vrijenhoek, R.C. (1998). Vestimentiferan on a whale fall. Biol. Bull., 194, 116-119.

Fisher, C.R.; MacDonald, I.R.; Sassen, R.; Young, C.M.; Macko, S.A.; Hourdez, S.; Carney, R.S.; Joye, S. \& McMullin, E. (2000). Methane ice worms: Hesiocaeca methanicola colonizing fossil fuel reserves. Naturwissenschaften 87, 184-487.

Folmer, O., Black, M., Hoeh, W., Lutz, R. \& Vrijenhoek, R. (1994). DNA primers for amplification of mitochondrial cytochrome $\mathrm{c}$ oxidase subunit I from diverse metazoan invertebrates. Mol. Mar. Biol. Biotec., 3(5), 294-299.

Fu, Y.X. (1997). Statistical tests of neutrality of mutations against population growth, hitchhiking and background selection. Genetics 147(2), 915-925.

Fujikura, K., Fujiwara, Y. \& Kawato, M. (2006). A new species of Osedax (Annelida: Siboglinidae) associated with whale carcasses off Kyushu, Japan. Zool. Sci. 23(8), 733740.

Fujiwara, Y., Kawato, M., Noda, C., Kinoshita, G., Yamanaka, T., Fujita, Y., Uematsu, K. \& Miyazaki, J.I. (2010). Extracellular and mixotrophic symbiosis in the whale-fall mussel Adipicola pacifica: a trend in evolution from extra- to intracellular symbiosis. PLoS One 5(7), e11808. doi:10.1371/journal.pone.0011808.

Fujiwara, Y., Kawato, M., Yamamoto, T., Yamanaka, T., Sato-Okoshi, W., Noda, C., Tsuchida, S., Komai, T., Cubelio, S.S., Sasaki, T., Jacobsen, K., Kubokawa, K., Fujikura, K., Maruyama, T., Furushima, Y., Okoshi, K., Miyake, H., Miyazaki, M., Nogi, Y., Yatabe, A. \& Okutani, T. (2007). Three-year investigations into sperm whale-fall ecosytems in Japan. Mar. Ecol., 28, 219-232.

Galtier, N., Nabholz, B., Glémin, S. \& Hurst, G.D.D. (2009). Mitochondrial DNA as a marker of molecular diversity: a reppraisal. Mol. Ecol. 18, 4541-4550.

Gamenick, I.; Abbiati, M. \& Giere, O. (1998). Field distribution and sulphide tolerance of Capitella capitata (Annelida: Polychaeta) around shallow water hydrothermal vents off Milos (Aegean Sea). A new sibling species? Mar. Biol. 130, 447-453. 
Georgieva, M.N.; Wiklund, H.; Bell, J.B.; Eilersten, M.H.; Milles, R.A.; Little, C.T.S. \& Glover, A.G. (2015). A chemosynthetic weed; the tubeworm Sclerolinum contortum is a bipolar cosmopolitan species. BMC Evol. Biol. 15, 280. DOI 10.1186/s12862-015-0559-y

Glover, A.G., Goetze, E., Dahlgren, T.G. \& Smith, C.R. (2005a). Morphology, reproductive biology and genetic structure of the whale-fall and hydrothermal vent specialist, Bathykurila guaymasensis Pettibone, 1989 (Annelida: Polynoidae). Mar. Ecol., 26, 223234.

Glover, A.G., Higgs, N.D., Bagley, P.M., Carlsson, R., Davies, A.J., Kemp, K.M., Last, K.S., Norling, K., Rosenberg, R., Wallin, K., Källström, B. \& Dahlgren, T.G. (2010). A live video observatory reveals temporal processes at a shelf-depth whale-fall. Cah. Biol. Mar., 51, 375-381.

Glover, A.G., Källström, B., Smith, C.R. \& Dahlgren, T.G. (2005b). World-wide whale worms? A new species of Osedax from the shallow north Atlantic. Proc. R. Soc. 272, 2587-2592.

Glover, A.G., Wiklund, H., Taboada, S., Avila, C., Cristobo, J., Smith, C.R., Kemp, K.M., Jamieson, A.J. \& Dahlgren, T.G. (2013). Bone-eating worms from the Antarctic: the contrasting fate of whale and wood remains on the Southern Ocean seafloor. Proc. R. Soc. B 280, 20131390. Doi:10.1098/rspb.2013.1390.

Goffredi, S.K., Johnson, S.B. \& Vrijenhoek, R.C. (2007). Genetic diversity and potential function of microbial symbionts associated with newly discovered species of Osedax polychaete worms. Appl. Environ. Microbiol., 73, 2314-2323.

Goffredi, S.K., Orphan, V.J., Rouse, G.W., Jahnke, L., Embaye, T., Turk. K., Lee, R. \& Vrijenhoek, R.C. (2005). Evolutionary innovation: a bone-eating marine symbiosis. Environ. Microbiol., 7, 1369-1378.

Goffredi, S.K., Paull, C.K., Fulton-Bennett, K., Hurtado, L.A. \& Vrijenhoek, R.C. (2004). Unusual benthic faunal associated with a whale fall in Monterey canyon, California. Deep Sea Res. I, 51, 1295-1306.

Goffredi, S.K., Wilpiszeski, R., Lee, R. \& Orphan, V.J. (2008). Temporal evolution of methane cycling and phylogenetic diversity of archaea in sediments from a deep-sea whale-fall in Monterey Canyon, California. ISME J., 2, 204-220.

Goffredi, S.K., Yi, H., Zhang, Q., Klann, J.E., Struve, I.A., Vrijenhoek, R.C. \& Brown, C.T. (2013). Genomic versatility and functional variation between two dominant heterotrophic symbionts of deep-sea Osedax worms. ISME J., 8, 908-924.

Gooday, A.J. (2002). Biological responses to seasonally varying fluxes of organic matter to the ocean floor: a review. J. Oceanogr., 58, 305-332.

Grassle, J.F. \& Grassle, J.P. (1974). Opportunistic life histories and genetic systems in marine benthic polychaetes. J. Mar. Res. 32(2), 253-284.

Grassle, J.P. \& Grassle, J.F. (1976). Sibling species in the marine pollution indicator Capitella (Polychaeta). Science, 192, 567-569.

Halanych, K. M. \& Janosik, A. M. (2006). A review of molecular markers used for Annelid phylogenetics. Integr. Comp. Biol. 46(4), 533-543.

Hartman, O. (1959). Capitellidae and Nereidae (Marine annelids)from gulf of Florida, with a review of freshwater Nereidae. Bull. Mar. Sci. Gulf Caribbean 9(2), 153-168.

Hebert, P. D., Cywinska, A. \& Ball, S. L. (2003a). Biological identifications through DNA barcodes. Proc. R. Soc. B 270(1512), 313-321.

Hebert, P. D., Ratnasingham, S. \& de Waard, J. R. (2003b). Barcoding animal life: cytochrome $\mathrm{C}$ oxidase subunit 1 divergences among closely related species. Proc. R. Soc. B 270(Suppl 1), S96-S99.

Hessler, R.R. \& Jumars, P A. (1974). Abyssal community analysis from replicate cores in the central North Pacific. Deep-Sea Res. Oceanogr. Abstr. 21(3), 185-209.

Hessler, R.R., Ingram, C.L., Aristides-Yayanos, A. \& Burnett, B.R. (1978). Scavenging amphipods from the floor of the Philippine Trench. Deep Sea Res. I, 25, 1029-1030.

Higgs, N.D., Gates, A.R. \& Jones, D.O. (2014). Fish food in deep sea: revisiting the role of large food-falls. PLoS ONE, 9(5), e96016. doi:10.1371/journal.pone.0096016. 
Higgs, N.D., Glover, A.G., Dahlgren, T. \& Little, C.T.S. (2011b). Bone-boring worms: characterizing the morphology, rate, and method of bioerosion by Osedax mucofloris (Annelida, Siboglinidae). Biol. Bull., 221, 307-316.

Higgs, N.D., Little, C.T.S. \& Glover, A.G. (2011a). Bones as biofuel: a review of whale bone composition with implications for deep-sea biology and paleoanthropology. Proc. R. Soc. B, 278(1702), 9-17.

Hilário, A., Cunha, M.R., Génio, L., Marçal, A.R., Ravara, A., Rodrigues, C.F. \& Wiklund, H. (2015). First clues on the ecology of whale falls in the deep Atlantic Ocean: results from an experimente using cow carcasses. Mar. Ecol., 36(S1), 82-90.

Hilliard, J.; Hajduk, M. \& Schulze, A. (2016). Species delineation in the Capitella species complex (Annelida: Capitellidae): geographic and genetic variation in the northern Gulf of Mexico. Invert. Biol. 135(4), 415-422.

Hillis, D.M. \& Dixon, M.T. (1991). Ribosomal DNA: molecular evolution and phylogenetic inference. Q. Rev. Biol. 66(4), 411-453.

Hogg, N.G. \& Owens, W.B. (1999). Direct measurement of the deep circulation within the Brazil Basin. Deep-Sea Res. II 46, 335-353.

Hogg, N.G., Siedler, G. \& Zenk, W. (1999). Circulation and variability at the southern boundary of the Brazil Basin. J Phys. Oceanogr. 29, 145-157.

ICZN (International Commission on Zoological Nomenclature) (1999). International Code of Zoological Nomenclature, 4th edition. London: International Trust dor Zoological Nomemnclature. Xxix, 306pp.

IWC (International Whaling Commission). (2013). Report of the Sub-Committee on in-depth assessments. Annex G. J. Cetacean Res. Manage. 14(suppl.), 192-213.

Jones, E., Collins, M., Bagley, P., Addison, S. \& Priede, I. (1998). The fate of cetacean carcasses in the deep sea: observations on consumption rates and succession of scavenging species in the abyssal north-east Atlantic Ocean. Proc. R. Soc. B 265, 11191127.

Jones, W.J., Johnson, S.B. Rouse, G.W. \& Vrijenhoek, R.C. (2008). Marine worms (genus Osedax) colonize cow bones. Proc. R. Soc. B 275, 387-391.

Kanaya, G.; Uehara, T. \& Kikuchi, E. (2016). Effects of sedimentary sulfide on community structure, population dynamics, and colonization depth of macrozoobenthos in organicrich estuarine sediments. Mar. Poll. Bull. 109(1), 393-401.

Katoh, K. \& Standley, D. M. (2013). MAFFT multiple sequence alignment software version 7: improvements in performance and usability. Mol. Biol. Evol. 30(4), 772-780.

Katz, S., Klepal, W. \& Bright, M. (2011). The Osedax trophosome: organization and ultrastructure. Biol. Bull. 220, 128-139.

Kearse, M., Moir, R., Wilson, A., Stones-Havas, S., Cheung, M., Sturrock, S., Buxton, S., Cooper, A., Markowitz, S., Duran, C., Thierer, T., Ashton, B., Meintjes, P. \& Drummonf, A. (2012). Geneious Basic: an integrated and extendable desktop software platform for the organization and analysis of sequence data. Bioinformatics, 28(12), 1647-1649.

Kemp, K., Jamieson, A., Bagley, P., McGrath, H., Bailey, D., Collins, M. \& Priede, I. (2006). Consumption of large bathyal food fall, a six month study in the NE Atlantic. Mar. Ecol. Prog. Ser. 310, 65-76.

Kiel, S. (2016). A biogeographic network reveals evolutionary links between deep-sea hydrothermal vent and methane seep faunas. Proc. R. Soc. B, 283, 20162337.

Kiel, S. (2017). Reply to Smith et al.: Network analysis reveals connectivity patterns in the continuum of reducing ecosystems. Proc. R. Soc. B, 284, 20171644.

Kiel, S., Kahl, W.-A. \& Goedert, J.L. (2011). Osedax borings in fossil marine bird bones. Naturwissenschaften 98, 51-55.

Knowlton, N. \& Weigt, L.A. (1997). Species of marine invertebrates: a comparison of the biological and phylogentic species concepts. In Claridge, M.F.; Dawah, H.A. and Wilson, M.R. (eds), Species: the units of biobiversity. Chapman \& Hall, London: 199-219.

Krogh, A. (1934). Conditions of life at great depths in the ocean. Ecol. Monogr., 4, 430-439. 
Kumar, S., Stecher, G. \& Tamura, K. (2016). MEGA7: Molecular Evolutionary Genetics Analysis version 7.0 for bigger datasets. Molecular biology and evolution, 33(7), 18701874.

Lanfear, R., Frandsen, P. B., Wright, A. M., Senfeld, T. \& Calcott, B. (2016). PartitionFinder 2: new methods for selecting partitioned models of evolution for molecular and morphological phylogenetic analyses. Molecular biology and evolution, 34(3), 772-773.

Le, H.L.V.; Lecointre, G. \& Perasso, R. (1993). A 28S rRNA-based phylogeny of the Gnathostomes: first steps in the analysis of conflict and congruence with morphologically based cladogram. Mol. Phylog. Evol. 2(1), 31-51.

Legendre, P. \& Gallagher, E.D. (2001). Ecologically meaningful transformations for ordination of species data. Oecologia 129, 271-280.

Leigh, J. W. \& Bryant, D. (2015). popart: full-feature software for haplotype network construction. Methods in Ecology and Evolution, 6(9), 1110-1116.

Levin, L.A., Mendoza, G.F., Konotchick, T. \& Lee, R. (2009). Macrobenthos community structure and trophic relationships within active and inactive Pacific hydrothermal sediments. Deep-Sea Res. II, 56(19-20), 1632-1648.

Levin, L.A.; Ziebis, W.; Mendonza, G.F.; Growney-Cannon, V. \& Walther, S. (2006). Recruitment response of methane-seep macrofauna to sulfide-rich sediments: An in situ experiment. J. Exper. Mar. Biol. Ecol. 330, 132-150.

Li, Y., Kocot, K. M., Schander, C., Santos, S. R., Thornhill, D. J. \& Halanych, K. M. (2015). Mitogenomics reveals phylogeny and repeated motifs in control regions of the deep-sea family Siboglinidae (Annelida). Mol. Phylogenetics Evol. 85, 221-229.

Lobo, J., Teixeira, M.A.L., Borges, L.M.S., Ferreira, M.S.G., Hollatz, C., Gomes, P.T., Sousa, R., Ravara, A., Costa, M.H. \& Costa, F.O. (2016). Starting a DNA barcode reference library for shallow water polychaetes from the European Atlantic coast. Mol. Ecol. Resour. 16(1), 298-313.

Lodi, L., Siciliano, S. \& Bellini, C. (1996). Ocorrências e conservação de baleias-francas-dosul, Eubalaena australis, no litoral do Brasil. Papéis Avulsos de Zool., S. Paulo. 39(17), 307-328.

Lorion, J., Duperron, S., Gros, O., Cruaud, C. \& Samadi, S. (2009). Several deep-sea mussels and their associated symbionts are able to live both on wood and on whale falls. Proc. Biol. Sci., 276, 177-185.

Lorion, J., Kiel, S., Faure, B., Kawato, M., Ho, S.Y.W., Marshall, B., Tsushida, S., Miyazaki, JI. \& Fujiwara, Y. (2013). Adaptive radiation of chemosymbiotic deep-sea mussels. Proc. R. soc. B, 280, 20131243.

Lundsten, L., Paull, C.K., Schlining, K.L., McGann, M. \& Ussler III, W. (2010b). Biological characterization of a whale-fall near Vancouver Island, British Columbia, Canada. Deep Sea Res. I, 57, 918-922.

Lundsten, L., Schlining, K.L., Frasier, K., Johnson, S.B., Kuhnz, L.A., Harvey, J.B.J., Clague, G. \& Vrijenhoek, R.C. (2010a). Times-series analysis of six whale-fall communities in Monterey Canyon, California, USA. Deep Sea Res. I, 57, 1573-1584.

Maddison, W.P. \& Maddison, D.R. (2018). Mesquite: a modular system for evolutionary analysis. Version 3.40

Magalhães, W.F. \& Blake, J.A. (2017). Capitellidae Grube, 1862. In: Westheide, W. and Purschke, G. (eds). Handbook of Zoology. A natural history of the phyla of the Animal kingdom. Annelida: Polychaetes. De Gruyter. Osnabrück. Handbook of Zoology Online.

McCartney, M.S. (1993). Crossing of the Equator by the Deep Western Boundary Current in the Western Atlantic Ocean. J. Phys. Oceanogr. 23, 1953-1974

Meißner, K.; Bick, A. \& Götting, M. (2016) Arctic Pholoe (Polychaeta; Pholoidae); when integrative taxonomy helps to sort out barcodes. Zool. J. linn. Soc. 179(2), 237-262.

Mémery, L., Arhan, M., Alvarez-Salgado, X.A., Messias, M.-J., Mercier, H., Castro, C.G. \& Rios, A.F. (2000). The water masses along the western boundary of the south and equatorial Atlantic. Prog. Ocenogr. 47, 69-98. 
Mendez, N. (2002). Experimental evidence of polymorphysm of sexual development in Capitella sp. B (Polychaeta: Capitellidae) from Barcelona, Spain. Sci. Mari. 66(2), 103110.

Mendez, N.; Linke-Gamenick, I. \& Forbes, V.E. (2000). Variability in reproductive mode and larval development within the Capitella capitata species complex. Invertebr. Repr. Dev. 38(2), 131-142.

Miyamoto, N., Yamamoto, T., Yusa, Y. \& Fujiwara Y. (2013). Postembryonic development of the bone-eating worm Osedax japonicus. Naturwissenschaften, 100, 285-289.

Miyazaki J-I, Martins LdO, Fujita Y, Matsumoto H. \& Fujiwara Y. (2010). Evolutionary process of deep-sea Bathymodiolus mussels. PLoS ONE 5(4), e10363. doi:10.1371/journal.pone.0010363.

Moura, C.J.; Cunha, M.R.; Porteiro, F.M. \& Rogers, A. D. (2011). The use of the DNA barcode gene 16S mRNA for the clarification of taxonomic problems within the family Sertulariidae (Cnidaria, Hydrozoa). Zool. Scr. 40(5), 520-537.

Murtagh, F. \& Legendre, P. (2014). Ward's hierarchical agglomerative clustering method: which algorithms implement Ward's criterion? J. Classification 31, 274-295.

Naganuma, T., Wada, H. \& Fujioka, K. (1996). Biological community and sediment fatty acids associated with the deep-sea whale skeleton at the Torishima seamount. J. Oceanogr., 52, $1-15$.

Nygren, A. (2014). Cryptic polychaete diversity: a review. Zool. Scr. 43(2), 172-183.

Paiva, P.C. \& Barroso, R. (2010). Polychaeta. In: Lavrado, H.P. and Brasil, A.C.S (orgs). Biodiversidade da região oceânica profunda da Bacia de Campos: Macrofauna. Rio de Janeiro/RJ, Brazil: SAG Serv. 99-171.

Paiva, P.C. \& Costa-Paiva, E.M. (2007). Filo Annelida, Classe Polychaeta. In: Lavrado, H.P \& Viana, M.S. (eds.). Atlas de invertebrados marinhos da região central da Zona Econômica Exlusiva brasileira, parte 1. Série Livro, 25. Rio de Janeiro: Museu Nacional. 133-162.

Palumbi, S. R., Martin, A., Romano, S., McMillan, W. O., Stice, L. \& Grabowski, G. (1991). The Simple Fool's Guide to PCR, Version 2.0, privately published document compiled by S. Palumbi. Dept. Zoology, Univ. Hawaii, Honolulu, HI, 96822.

Paterson, G.L.J.; Glover, A.G.; Froján, C.R.S.; Whitaker, A.; Budaeva, N.; Chimonides, J. \& Doner, S. (2009). A census of abyssal polychaetes. Deep. Sea Res. Part II: Top. Stud. Oceanogr. 56, 1739-46.

Pearson, M. \& Pearson, T.H. (1991). Variation in populations of Capitella capitata (Fabricius, 1780)(Polychaeta) from the west coast of Scotland. Ophelia Suppl, 5(363), e370.

Pereira, O., Shimabukuro, M., Bernardino, A.F. \& Sumida, P.Y.G. (in prep). Occurence of Alvinocaris muricola in whale bonés from the Southwest Atlantic Ocean: molecular affinity to the Atlantic Equatorial Belt population. Article in prep. to submit to DSRI.

Perez, F.V. (2016). Diversidade e conectividade de comunidades bacterianas em substratos sintéticos e orgânicos no Atlântico Sudoeste profundo. Master Thesis, (in portuguese). Retrieved from Teses USP: http://www.teses.usp.br/teses/disponiveis/42/42132/tde19012017-115607/pt-br.php

Pettibone, M.H. (1993). Polynoid polychaetes associated with a whale skeleton in the bathyal Santa Catalina basin. Proc. Biol. Soc. Wash. 106(4), 678-688.

Pleijel, F. (1998). Phylogeny and classification of Hesionidae (Polychaeta). Zool. Scri., 27(2), 89-163.

Pleijel, F. (2004). A revision of Hesiospina (Psamathini, Hesionidae, Polychaeta). J. Nat. Hist. 38(20), 2547-2566.

Pleijel, F. \& Rouse, G. (2005). A revision of Micropodarke (Psamathini, Hesionidae, Polychaeta). J. Nat. Hist. 39(17), 1313-1326.

Pleijel, F., Rouse, G. W. \& Nygren, A. (2012). A revision of Nereimyra (Psamathini, Hesionidae, Aciculata, Annelida). Zool. J. Linn. Soc. 164(1), 36-51.

Pleijel, F., Rouse, G.W., Ruta, C., Wiklund, H. \& Nygren, A. (2008). Vrijenhoekia balaenophila, a new hesionid polychaete from a whale fall off California. Zool. J. Linn. Soc., 152, 625-634. 
Plouviez, S., Jacobson, A., Wu, M. \& Van Dover, C.L. (2015). Characterization of vent fauna at the Mid-Cayman Spreading Center. Deep Sea Res. I, 97, 124-133.

Qian, P.Y. \& Chia, F.S. (1991). Effects of diet type on the demographics of Capitella sp. (Annelida: Polychaeta): lecithotrophic development vs. planktotrophic development. J. Exp. Mar. Biol. Ecol. 157, 159-179.

Ramirez-Llodra, E., Brandt, A., Danovaro, R., De Mol, B., Escobar, E., German, C.R., Levin, L.A., Marteinez-Arbizu, P., Menot, L., Buhl-Mortensen, P., Narayanaswamy, B.E., Smith, C.R., Tittensor, D.P., Tyler, P.A., Vanreusel, A. \& Vecchione, M. (2010). Deep. diverse and definitely different: unique attributes of the world's largest ecosystem. Biogeosciences 7, 2851-2899.

Ramskov, T. \& Forbes, V.E. (2008). Life history and population dynamics of the opportunistic polychaete Capitella sp. I in relation to sediment organic matter. Mar. Ecol. Prog. Ser. 369, 181-192.

Ravara, A., Marçal, A.R., Wiklund, H. \& Hilário, A. (2015). First account on the diversity of Ophryotrocha (Annelida, Dorvilleidae) from a mammal-fall in the deep-Atlantic Ocean with the description of three new species. Syst. Biod., 13(6), 555-570.

Roman, J., Estes, J.A., Morissette, L., Smith, C., Costa, D., McCarthy, J., Nation, J.B., Nicol, S., Pershing, A. \& Smetacek, V. (2014). Whales as marine ecosystem engineers. Front. Ecol. Environ. 2014; doi:10.1890/130220.

Ronquist, F.; Teslenko, M.; van der Mark, P.; Ayres, D.L.; Darling, A.; Höhna, S.; Larget, B.; Liu, L.; Suchard, M.A. \& Huelsenbeck, J.P. (2012). MrBayes v. 3.2: efficient Bayesian phylogenetic inference and model choice across a large model space. Syst. Biol. 61, 539-542.

Rouse, G.W., Goffredi, S.K. \& Vrijenhoek, R.C. (2004). Osedax: bone-eating marine worms with dwarf males. Science, 30,: 668-671.

Rouse, G.W., Goffredi, S.K., Johnson, S.B. \& Vrijenhoek, R.C. (2018). An inordinate fondness for Osedax (Siboglinidae: Annelida): fourteen new species of bone worms from California. Zootaxa 4377(4), 451-489.

Rouse, G.W., Wilson, N.G., Goffredi, S.K., Johnson, S.B., Smart, T., Widmer, C., Young, C.M. \& Vrijenhoek, R.C. (2009). Spawning and development in Osedax boneworms (Siboglinidae, Annelida). Mar. Biol. 156, 395-405.

Rouse, G.W., Wilson, N.G., Worsaae, K. \& Vrijenhoek, R.C. (2015). A dwarf male reversal in bone-eating worms. Curr. Biol., 25,1-6. doi.10.1016/j.cub.2014.11.032

Rouse, G.W., Worsaae, K., Johnson, S.B., Jones, W.J. \& Vrijenhoek, R.C. (2008). Acquisition of dwarf male "harems" by recently settled females of Osedax rouseus $\mathrm{n}$. $\mathrm{sp}$. (Siboglinida; Annelida). Biol. Bull., 214, 67-82.

Rozas, J., Librado, P., Sánchez-Del Barrio, J. C., Messeguer, X., \& Rozas, R. (2010). DnaSP version 5 help contents [Help File]. Available with the program at http://www. ub. edu/dnasp.

Ruta, C. \& Pleijel, F. (2006). A revision of Syllidia (Psamathini, Hesionidae, Polychaeta). J. Nat. Hist., 40(9), 503-521.

Ruta, C.; Nygren, A.; Rousset, V.; Sundberg, P.; Tillier, A.; Wiklund, H. \& Pleijel, F. (2007). Phylogeny of Hesionidae (Aciculata, Polychaeta), assessed from morphology, 18S rDNA, 28S rDNA, 16S rDNA and COI. Zool. Scr. 36, 99-107.

Saeedi, H., Bernardino, A.F., Shimabukuro, M., Falchetto, G. \& Sumida, P.Y.G. (in prep.). Wood-fall experimente in the deep SW Atlantic - macrofaunal community structure and biodiversity patterns. Article in prep. to submit to DSRII.

Salathé, R.M. \& Vrijenhoek, R.C. (2012). Temporal variation and lack of host specificity among bacterial endosymbionts of Osedax bone worms (Polychaeta: Siboglinidae). BMC Evol. Biol. 12, 189. Doi:1471-2148/12/189

Santos, M.C.O., Siciliano, S., Vicente, A.F.C., Alvarenga, F.S., Zampirolli, E., Souza, S.P. \& Maranho, A. (2010). Cetacean records along São Paulo state coast Southeastern Brazil. Braz. J. Oceanogr., 58(2), 123-142.

Shimabukuro, M., Alfaro-Lucas, J.M., Bernardino, A.F., Ramos, R.B., Mahiques, M.M. \& Sumida, P.Y.G. (submitted). Chemosynthetic environments on the Brazilian deep-sea 
margin. Submitted as book chapter in: Sumida, P.Y.G., Bernardino, A.F. \& De Léo, F. (eds). Brazilian Deep-Sea Biodiversity.

Silva, C.F., Seixas, V.C.; Barroso, R., Di Domenico, M., Amaral, A.C.Z. \& Paiva, P.C. (2017). Demystifying the Capitella capitata complex (Annelida, Capitellidae) diversity by morphological and molecular data along the Brazilian coast. PLoS ONE 12(5): e0177760. https://doi.org/10.1371/journal.pone.0177760.

Silva, C.F., Shimabukuro, M., Alfaro-Lucas, J.M., Fujiwara, Y., Sumida, P.Y.G. \& Amaral, A.C.Z. (2016). A new Capitella polychaete worm (Annelida: Capitellidae) living inside whale bones in the abyssal South Atlantic. Deep Sea Res. I 108, 23-31.

Silva, M.B. \& Godoy, T., (2010). Avistagens oceânicas de cetáceos entre Natal e a Reserva Biológica do Atol das Rocas / RN. In Abstracts of the XIV Reunião de Trabalho (RT) de Especialistas em Mamíferos Aquáticos da América do Sul, 2010. Florianópolis: SOLAMAC.

Silveira, I.C.A., Schmidt, A.C.K., Campos, E.J.D., Godoi, S.S. \& Ikeda, Y. (2000). A corrente do Brasil ao largo da costa leste brasileira. Rev. Bras. Oceanogr. 48(2), 171-183.

Simon, C.; Frati, F.; Beckenbach, A; Crespi, B.; Liu, H. \& Flook, P. (1994). Evolution weighting, and phylogenetic utility of mitochondrial gene sequences and a compilation of conserved polymerase chain reaction primers. Ann. Entomol. Soc. Am. 87(6), 651-701.

Smith CR. (2006). Bigger is better: the role of whales as detritus in marine ecosystems. In: J.A. Estes, P. DeMaster,D.F. Doak, T.M. Williams, R.L. Brownell Jr (eds). Whales, Whaling and Ocean Ecosystems. Berkeley: Univ. Calif. Press. pp. 286-300.

Smith, C. (1985). Food for the deep sea: utilization, dispersal, and flux of nekton falls at the Santa Catalina basin floor. Deep Sea Res. A, 32(4), 417-442.

Smith, C.R. \& Baco, A.R. (2003). Ecology of whale falls at the deep-sea floor. Oceanogr. Mar. Biol. Ann. Rev., 41, 311-354.

Smith, C.R., Amon, D.J., Higgs, N.D., Glover, A.G. \& Young, E.L. (2017). Data are inadequate to test whale falls as chemosynthetic stepping-stones using network analysis: faunal overlaps do support a stepping-stone role. Proc. R. Soc. B, 284, 20171281.

Smith, C.R., Baco, A.R. \& Glover, A.G. (2002). Faunal succession on replicate deep-sea whale falls: time scales and vent-seep affinities. Cah. Biol. Mar., 43, 293-297.

Smith, C.R., Bernardino, A.F., Baco, A., Hannides, A. \& Altamira, I. (2014). Seven-year enrichment: macrofaunal succession in deep-sea sediments around a 30 tonne whale fall in the Northeast Pacific. Mar. Ecol. Prog. Ser., 515, 133-149.

Smith, C.R., Glover, A.G., Treude, T., Higgs, N.D. \& Amon, D.J. (2015). Whale-fall ecosystems: recent insights into ecology, paleoecology, and evolution. Annu. Rev. Mar. Sci., 7, 10.1-10.6.

Smith, C.R., Hoover, D.J., Doan, S.E., Pope, R.H., Demaster, D.J., Dobbs, F.C. \& Altabet, M.A. (1996). Phytodetritus at the abyssal seafloor across $10^{\circ}$ of latitude in the central equatorial Pacific. Deep Sea Res. II 43(4-6), 1309-1338.

Smith, C.R., Kukert, H., Wheatcroft, R.A., Jumars, P.A. \& Deming, J.W. (1989). Vent fauna on whale remains. Nature, 341, 27-28.

Smith, K.E.,, Thatje, S., Singh, H., Amsler, M.O., Vos, S.C., McClintock, J.B., Brothers, C.J., Brown, A., Ellis, D., Anderson, J.S. \& Aronson, R.B. (2014). Discovery of a recent, natural whale fall on the continental slope off Anvers Island, western Antarctic Peninsula. Deep Sea Res. I, 90, 76-80.

Srivathsan, A. \& Meier, R. (2012). On the inappropriate use of Kimura-2-parameter (K2P) divergences in the DNA- barcoding literature. Cladistics 28(2), 190-194.

Stamatakis, A. (2014). RAxML version 8: a tool for phylogenetic analysis and post-analysis of large phylogenies. Bioinformatics, 30(9), 1312-1313.

Stiller, J., Rousset, V., Pleijel, F., Chevaldonné, P., Vrijenhoek, R. C. \& Rouse, G. W. (2013). Phylogeny, biogeography and systematics of hydrothermal vent and methane seep Amphisamytha (Ampharetidae, Annelida), with descriptions of three new species. Syst. Biodivers. 11(1), 35-65. 
Stockton, W.L. \& DeLaca, T.E. (1982). Food falls in the deep sea: occurrence, quality and significance. Deep Sea Res. I, 29, 157-169.

Stramma, L. \& England, M. (1999). On the water masses and mean circulation of the South Atlantic Ocean. J. Geophys. Res. 104(C9), 20,863-20,883.

Sumida, P.Y.G., Alfaro-Lucas, J.M., Shimabukuro, M., Kitazato, H., Perez, J.A.A., SoaresGomes, A., Toyofuku, T., Lima, A.O.S., Ara, K \& Fujiwara, Y. (2016). Deep-sea whale fall fauna from the Atlantic resembles that of the Pacific Ocean. Sci. Rep., 6: 22139; doi: $10.1038 /$ srep22139.

Summers, M., Pleijel, F. \& Rouse, G.W. (2015). Whale falls, multiple colonization of the deep, and the phylogeny of Hesionidae (Annelida). Invert. Syst., 29, 105-123.

Taboada, S., Riego, A., Bas, M., Arnedo, M.A., Cristobo, J., Rouse, G.W. \& Avila, C. (2015). Bone-eating worms spread: insights into shallow-water Osedax (Annelida, Siboglinidae) from Antarctic, Subantarctic, and Mediterranean waters. PLoS ONE 10(11), e0140341. Doi:10.1371/journal.pone.0140341.

Taboada, S.; Bas, M.; Leiva, C.; Garriga, M.; Sardá, R. \& Avila, C. (2016). Life after death: shallow-water Mediterranean invertebrate communities associated with mammal bones. Mar. Ecol. 37(1), 164-178.

Taboada, S.; Wiklund, H.; Glover, A.G.; Dahlgren, T.G.; Cristobo, J. \& Avila, C. (2013). Two new Antarctic Ophryotrocha (Annelida: Dorvilleidae) described from shallow-water whale bones. Polar Biol. 36(7), 1031-1045.

Tajima, F. (1989). Statistical method for testing the neutral mutation hypothesis by DNA polymorphism. Genetics 123(3), 585-595.

Teixeira, S., Olu, K., Decker, C., Cunha, R.L., Fuchs, S., Hourdez, S., Serrão, E.A. \& ArnaudHaond, S. (2013). High connectivity across the fragmented chemosynthetic ecosystems of the deep Atlantic Equatorial Belt: eficiente dispersal mechanisms or questionable endemismo? Mol. Ecol., 22, 4663-4680.

Tenore, K.RT. (1981). Organic nitrogen and caloric content of detritus. Estuar. Coast. S. Sci. 12, 39-47.

Thiyagarajan, V., Soo, L., Shin, P.K.S. \& Qian, P.Y. (2006). Spatio-temporal variation in sediment biochemistry alters larval habitat selection and juvenile performance in the polychaete Capitella sp. I. Mar. Ecol. Prog. Ser. 327, 207-222.

Thiyagarajan, V.; Soo, L. \& Qian, P.Y. (2005). The role of sediment organic matter composition in larval habitat selection by the polychaete Capitella sp. I. J. Exp. Mar. Biol. Ecol. 323, 70-83.

Thornhill, D.J.; Struck, T.H.; Ebbe, B.; Lee, R.W.; Mendoza, G.F.; Levin, L.A. \& Halanych, H.M. (2012). Adaptive radiation in extremophilic Dorvilleidae (Annelida): diversification of a single colonizer or multiple independent lineages? Ecol. Evol. 2(8), 1958-1970.

Thubaut, J.; Puillandre, N.; Faure, B.; Cruaud, C. \& Samadi, S. (2013). The contrasted evolutionary fates of deep-sea chemosynthetic mussels (Bivalvia, Bathymodiolinae). Ecol. Evol. 3(14), 4748-4766. doi:10.1002/ece3.749

Tomioka, S.; Kondoh, T.; Sato-Okoshi, W.; Ito, K.; Kakui, K. \& Kajihara, H. (2016). Cosmopolitan or cryptic species? A case study of Capitella teleta (Annelida: Capitellidae). Zool. Sci. 33, 545-554.

Tresguerres, M., Katz, S. \& Rouse, G.W. (2013). How to get into bones: proton pump and carbonic anhydrase in Osedax boneworms. Proc. R. Soc. B, 208, 20130625. doi.10.1098/rspb.2013.0625.

Treude, T., Smith, C.R., Wenshafer, F., Carney, E., Bernardino, A.F., Hannides, A.K. \& Boetius, A. (2009). Biogeochemistry of a deep-sea whale fall: sulfate reduction, sulfide efflux and methagenesis. Mar. Ecol. Prog. Ser., 382, 1-21.

Tsutsumi, H., Wainright, S., Montani, S., Saga, M., Ichihara, S. \& Kogure, K. (2001). Exploitation of a chemosynthetic food resource by the polychaete Capitella sp. I. Mar. Ecol. Prog. Ser. 216, 119-127.

Tunnicliffe, V, \& Juniper, S.K. (1990). Cosmopolitan underwater fauna. Nature 344, 300.

Turner, J.T. (2002). Zooplankton fecal pellets, marine snow and sinking phytoplankton blooms. Aquat. Microb. Ecol., 27, 57-102. 
Turner, R.D. (1973). Wood-boring bivalves, opportunistic species in the deep sea. Science, 180(4093), 1377-1379.

Vetter, E.W. \& Dayton, P.K. (1998) Macrofaunal communities within and adjacent to a detritus-rich submarine canyon system. Deep-Sea Res. II 45, 25-54.

Vrijenhoek, R. C., Johnson, S. B. \& Rouse, G. W. (2009). A remarkable diversity of boneeating worms (Osedax; Siboglinidae; Annelida). BMC Biology 7(1), 74. Doi:10.1186/1741-7007-7-74.

Vrijenhoek, R.C., Johnson, S.B. \& Rouse, G.W. (2008). Bone-eating Osedax females and their 'harems' of dwarf males are recruited from a common larval pool. Mol. Ecol. 17, 4535-4544.

Wada, M., Wu, S.S., Tsutsumi, H., Kita-Tsukamoto, K., Hyung-Ki, D., Nomura, H., Ohwada, K. \& Kogure, K. (2006). Effects of sodium sulfide on burrowing activity of Capitella sp. I and bacterial respiratory activity in seawater soft-agar microcosms. Plankton and Benthos Research 1(2), 117-122.

Watson, C., Carvajal, J.I., Sergeeva, N.G., Pleijel, F. \& Rouse, G.W. (2016). Free-living calamyzin chrysopetalids (Annelida) from methane seeps, anoxic basins, and whale falls. Zool. J. Linn. Soc., 177, 700-719.

Wedekin, L.L., Rossi-Santos, M.R., Baracho, C., Cypriano-Souza, A.L. \& Simões-Lopes, P.C. (2014). Cetacean records along a coastal-offshore gradient in the Vitória-Trindade Chain, western South Atlantic Ocean. Braz. J. Biol. 74(1), 137-144.

Wiklund, H., Altamira, I.V., Glover, A.G., Smith, C.R., Baco, A.R. \& Dahlgren, T.G. (2012). Systematics and biodiversity of Ophryotrocha (Annelida, Dorvilleidae) with descriptions of six new species from deep-sea whale-fall and wood-fall habitats in the north-east Pacific. Syst. Biodivers. 10(2), 243-259.

Wiklund, H., Glover, A..G., Johannessen, P.J. \& Dahlgren, T.G. (2009a). Cryptic speciation at organic-rich marine habitats: a new bacteriovore annelid from whale-fall and fish farms in the North-East Atlantic. Zool. J. Linn. Soc. 155, 774-785.

Wiklund, H., Glover, A.G. \& Dahlgren, T.G. (2009b). Three new species of Ophryotrocha (Annelida: Dorvilleidae) from a whale-fall in the North-East Atlantic. Zootaxa 2228, 43-56.

Wolff, T. (1979). Macrofaunal utilization of plant remains in the deep sea. Sarsia 64, 1-2.

Worsaae, K. \& Rouse, G.W. (2010). The simplicity of males: dwarf males of four species of Osedax (Siboglinidae: Annelida) investigated by confocal laser scanning microscopy. J. Morph., 271, 127-142.

Young, C.M., He, R., Emlet, R.B., Li, Y., Qian, H., Arellano, S.M., Gaest, A.V., Bennett, K.C., Wolf, M., Smart, T.I. \& Rice, M.E. (2012). Dispersal of deep-sea larvae from IntraAmerican Seas: simulations of trajectories using ocean models. Integr. Comp. Biol. 52(4), 483-496.

Zanol, J.; Halanych, K.M.; Struck, T.H. \& Fauchald, K. (2010). Phylogeny of the bristle worm family Eunicidae (Eunicidae, Annelida) and the phylogenetic utility of noncongruent 16S, $\mathrm{COI}$ and $18 \mathrm{~S}$ in combined analyses. Mol. Phylog. Evol. 55, 660-676.

Zerbini, A. N., Andriolo, A., Heide-Jørgensen, M. P., Pizzorno, J. L., Maia, Y. G., VanBlaricom, G. R., DeMaster, D.P., Simões-Lopes, P., Moreira, S. \& Bethlem, C. (2006). Satellite-monitored movements of humpback whales Megaptera novaeangliae in the Southwest Atlantic Ocean. Marine Ecology Progress Series, 313, 295-304.

Zerbini, A. N., Secchi, E. R., Siciliano, S., \& Simões-Lopes, P. C. (1997). A review of the occurrence and distribution of whales of the genus Balaenoptera along the Brazilian coast. Report of the International Whaling Commission, 47, 407-417. 